\title{
Assessment of the health status of wild fish inhabiting a cotton basin heavily impacted by pesticides in Benin (West Africa)
}

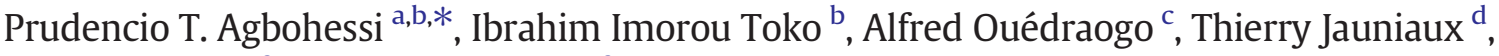 \\ S.N.M. Mandiki ${ }^{a}$, Patrick Kestemont ${ }^{\mathrm{a}}$ \\ a Research Unit in Environmental and Evolutionary Biology (URBE), University of Namur, Rue de Bruxelles 61, 5000 Namur, Belgium \\ b Research Unit in Aquaculture and Aquatic Ecotoxicology (URAEAq), University of Parakou, Benin \\ c Laboratory of Histology, Embryology and Molecular biology, University of Abomey-Calavi, Benin \\ ${ }^{\mathrm{d}}$ Department of General Pathology, Faculty of Veterinary Medicine, University of Liege, Belgium
}

\section{H I G H L I G H T S}

- Getting bioindicator species of pollutant in the aquatic ecosystem of beninese cotton basin.

- Obtaining biomarkers to characterize the estrogenic effects of pesticides.

- The pesticide effects are among the cause of the disappearance of certain species of fish in the cotton basin.

\section{A R T I C L E I N F O}

\section{Article history:}

Received 20 May 2014

Received in revised form 11 November 2014

Accepted 13 November 2014

Available online 27 November 2014

Editor: Daniel A. Wunderlin

\section{Keywords:}

Tilapia guineensis

Clarias gariepinus

Biomarkers

Sex steroids

Gonad and liver histopathology

\begin{abstract}
A B S T R A C T
To determine the impact of agricultural pesticides used in cotton cultivation on the health status of fish living in a Beninese cotton basin, we compared the reproductive and hepatic systems of fish sampled from rivers located in both contaminated and pristine conditions. Different types of biomarkers, including biometric indices (a condition factor K, a gonadosomatic index GSI, and a hepatosomatic index HSI), plasma levels of sex steroids (11ketotestosterone 11-KT, testosterone T and estradiol-173 E2) and the histopathology of the gonads and liver, were investigated for two different trophic levels of the following two fish species: the Guinean tilapia Tilapia guineensis and the African catfish Clarias gariepinus. The fish were captured during both the rainy season (when there is heavy use of pesticides on cotton fields) and the dry season from one site, in Pendjari River (reference site), which is located outside the cotton-producing basin, and from three other sites on the Alibori River within the cotton-producing basin. Comparing fish that were sampled from contaminated (high levels of endosulfan, heptachlor and DDT and metabolites) and reference sites, the results clearly indicated that agricultural pesticides significantly decreased K and GSI while they increased HSI, regardless of the season, species and sex of the fish. These pesticides also induced a decrease in the plasma levels of 11-KT and T and increased those of E2. The histopathology of the testes revealed, in both species, a high rate of testicular oocytes, up to $50 \%$ in the African catfish, downstream of the Alibori River, which indicated estrogenic effects from the pesticides. The disruption of male spermatogenesis primarily included necrosis, fibrosis and the presence of foam cells in the lobular lumen. The histopathology of the ovaries revealed high levels of pre-ovulatory follicular atresia, impaired oogenesis, a decrease in the oocyte vitellogenic diameter and other lesions, such as fibrosis, vacuolation and melano-macrophagic centers. The histopathology of the liver revealed the presence of necrosis, hypertrophic hepatocytes, foci of vacuolation, glycogen depletion and hemosiderin. An assessment of the general health of the fish indicated that all of the sampled fish from the polluted sites were in poorer health compared with those from the reference site but that the African catfish appeared much more affected than the Guinean tilapia, regardless of the sex and season. In conclusion, the overall results indicated that agricultural pesticides significantly impair the endocrine regulation of fish living in the Beninese cotton basin and that this would most likely be one of the causes of the severe damage observed in the liver and gonads and the reduced health condition.
\end{abstract}

c) 2014 Elsevier B.V. All rights reserved.
* Corresponding author at: Research Unit in Environmental and Evolutionary Biology, University of Namur, Rue de Bruxelles 61, B-5000 Namur, Belgium. Tel.: + 32499812655

E-mail address: agbohessip@yahoo.fr (P.T. Agbohessi).

\section{Introduction}

An increasing number of widely used chemicals are reported to possess endocrine activity that is capable of affecting the reproduction of 


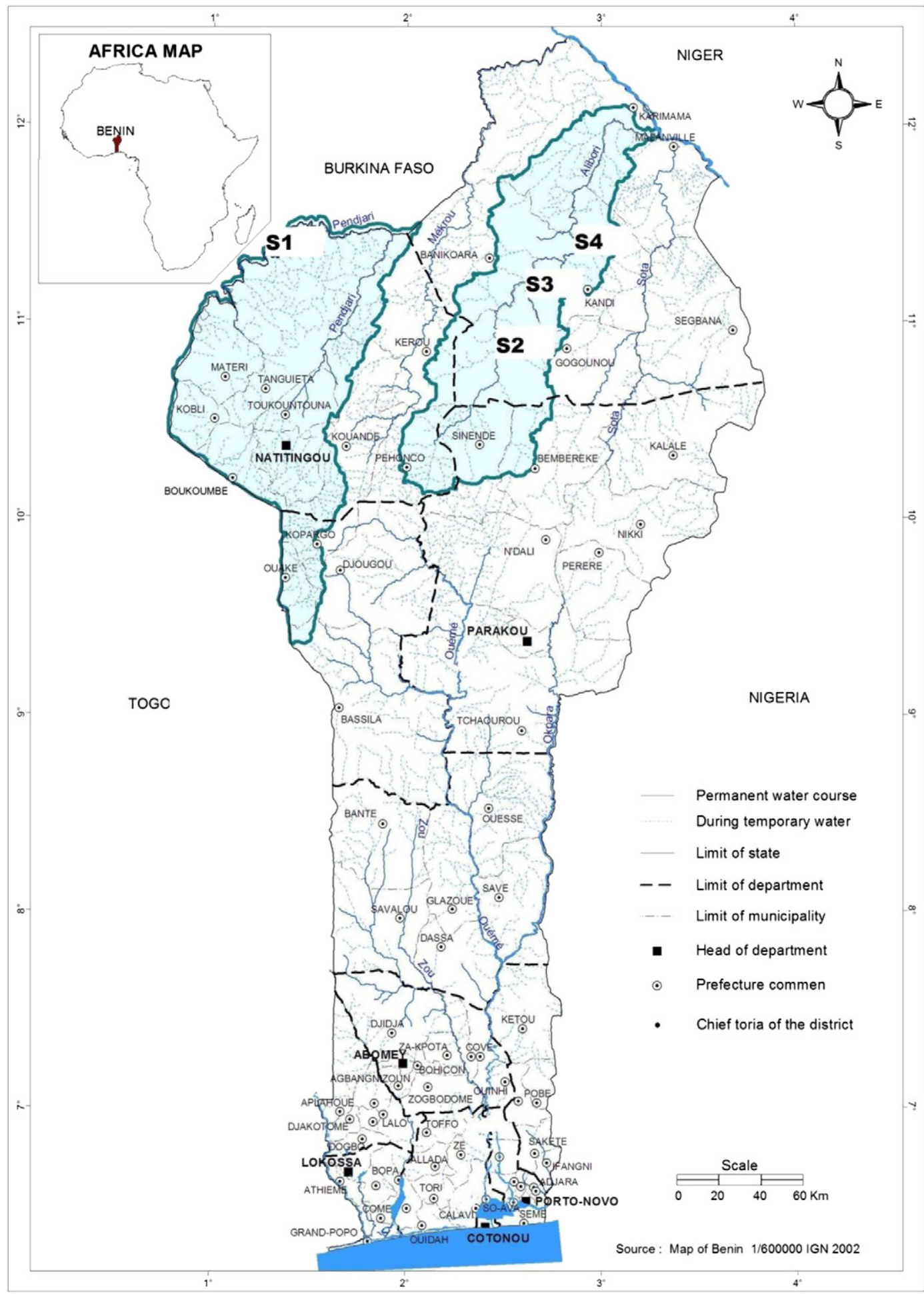

Fig. 1. Hydrographic map of Benin showing the study sites (S1: reference site on the Pendjari River, S2-S4: contaminated sites on the Alibori River).

wildlife populations (Rotchell and Ostrander, 2003). Among these chemicals, there are various types of agricultural pesticides that are applied in large quantities on field crops to ward against plant pests. Several studies have shown that only $0.1 \%$ of the applied pesticides reached the target pests (Primentel and Levitain, 1986; Grébil et al., 2001). Aquatic ecosystems are generally the final destination of pesticides used in agricultural production (Gillium, 2007; Chao et al., 2009). Other studies (Purdom et al., 1994; Gimeno et al., 1996; Barse et al., 2007; Micheletti et al., 2007; Singh and Singh, 2007; Mckinlay et al.,
2008; Palma et al., 2008, 2009a and b) have reported on the interactions of certain pesticides on the hypothalamic-pituitary-gonadal axis, demonstrating that these pollutants behave as endocrine disruptors that potentially alter fish reproduction and growth.

Among West African countries, Benin (Fig. 1) is known as the main producer of cotton. Large quantities of pesticides belonging to different chemical families (e.g., organochlorines, organophosphates, pyrethroids, neonicotinoids) have been and are still widely used, legally or not, by cotton producers (e.g., DDT, lindane, heptachlor, endrin, 
endosulfan, deltamethrin, acetamiprid) since 1960 to fight against cotton pests; they have also been used by fishermen (e.g., endosulfan, DDT, heptachlor) directly in the water to catch fish during low water periods (CENAGREF, 2004; Katary, 2004; Yèhouénou A. Pazou, 2005; Agbohessi et al., 2011; CeRPA Borgou-Alibori, 2013). Consequently, these agricultural pesticides are viewed as a major source of pollution in aquatic ecosystems, particularly in the sections of north Benin, where the most cotton is produced (up to $90 \%$ of national production according to the AIC (2009)). High levels of DDT (6.45-100 $\mu \mathrm{g} / \mathrm{L})$, endosulfan (58-746 $\mu \mathrm{g} / \mathrm{L})$, dieldrin (1-48 $\mu \mathrm{g} / \mathrm{L})$ and heptachlor $(34-83 \mu \mathrm{g} / \mathrm{L})$ were detected in the waters of Agbado (Savalou), Atacora, Djona and W Park Rivers (CENAGREF, 2004; Agagbé, 2008; Agbohessi et al., 2012). High concentrations of pollutants were detected in species of fish caught on the Ouémé River, including DDT levels up to $1642 \mathrm{ng} / \mathrm{g}$ in the lipids of African catfish Clarias gariepinus and dieldrin levels up to $750 \mathrm{ng} / \mathrm{g}$ in the lipids of West African longfish Protopterus annectens and $215 \mathrm{ng} / \mathrm{g}$ in the lipids of Silver catfish Schilbe intermedius (Yehouénou A. Pazou et al., 2006; Agbohessi et al., 2012). An investigation by Okounmassoun et al. (2002) in males of Blackchin tilapia Sarotherodon melanotheron from Ouémé River, revealed the presence of lindane (105 $\mu \mathrm{g} / \mathrm{g}$ ), dieldrin (75 $\mu \mathrm{g} / \mathrm{g})$, heptachlor (30 $\mu \mathrm{g} / \mathrm{g}), \mathrm{pp}^{\prime}$-TDE $(28.5 \mu \mathrm{g} / \mathrm{g})$ and a plasma vitellogenin concentration of $38 \mu \mathrm{g} / \mathrm{mL}$, suggesting possible endocrine disruption of fish in this River. Organochlorine pesticides that have contaminated these ecosystems in the remote past could still be present because of their high persistence (OMS, 1991). An investigation by Agbohessi et al. (2011) revealed that the pesticides recommended by the authorities in charge of agriculture in Benin are not those used by cotton producers. This survey indicated that the insecticides used at Banikoara, the highest cottonproducing municipality in Benin, included endosulfan (75.0\% of total volume) to the detriment of Tihan 175 O-TEQ (1.70\%) containing flubendiamide $(100 \mathrm{~g} / \mathrm{L})$ and spirotetramat $(75 \mathrm{~g} / \mathrm{L})$ as active matter, Nurelle D (21.0\%) with cypermethrin and chlorpyrifos-ethyl as active matter, and Thunder 145 O-TEQ (2.5\%) with betacyfluthrin (45 g/L) and imidacloprid $(100 \mathrm{~g} / \mathrm{L})$ as active matter. The herbicides Kalach $360 \mathrm{SL}$, containing glyphosate (360 g/L) as active matter, and Callifor $\mathrm{G}$, with promethrin, fluameturon and glyphosate as active ingredients, were the most widely used compounds. Although forbidden in Benin since 2007, endosulfan is still the most widely used insecticide in the Beninese cotton basin (Agbohessi et al., 2011). Considered an endocrine disruptor (WWF, 2011; OMS-PNUE, 2013), this insecticide inhibits the testes of male fish followed by morphological changes (e.g., atrophy of the lobules and degeneration of the spermatids and spermatozoa) (Srivastava and Srivastava, 1991; Wester, 1991; Foerson et al., 2001; Mckinlay et al., 2007; Palma et al., 2009a, 2009b). According to the Australian Pesticides and Veterinary Medicines Authority (2009), flubendiamide would also disrupt the endocrine glands and could bioaccumulate in fatty tissues. This pesticide has a harmful effect on the hatchability, fry survival and growth of the fathead minnow, Pimephales promelas. The toxicity of chlorpyrifos has been reported in fish such as the South European toothcarp, Aphanius fasciatus, (Boumaiza et al., 1979), Guinean tilapia, Tilapia guineensis, (Chinah et al., 2004), Nile tilapia, Oreochromis niloticus, (Gul, 2005; Oruç, 2010) and Asian stinging catfish, Heteropneustes fossilis, (Tripathi and Shasmal, 2011). Furthermore, in recent work, Oruç (2010) exhibited how chlorpyrifos, in addition to oxidative stress, acts as an endocrine disruptor in Nile tilapia. Although glyphosate did not induce estrogenic or androgenic effects in the early life stages of stickleback (Gasterosteus aculeatus) at environmentally significant concentrations (Le Mer et al., 2013), its presence at $3.6 \mathrm{mg} / \mathrm{L}$ in water was deleterious to female jundia (Rhandia quelen) reproduction, altering steroid profiles and egg viability (Soso et al., 2007). It was also proved that cypermethrin has estrogenic effects (Chen et al., 2002; McCarthy et al., 2006). Several other types of active matter used in the Beninese cotton basin also have harmful effects on the reproduction and growth of fish. Aquatic organisms, including fish, are immersed in a mixture of chemicals that may have other effects when combined (cocktail effect) and are different from their individual effects (Rajapakse et al., 2002; Hayes et al., 2006; WWF, 2011; OMS-PNUE, 2013). Despite the widespread pollution of aquatic ecosystems by agricultural pesticides, and the disappearance of many fish species from contaminated rivers (MEPN, 2009), there are only a few studies about the impact of these biocides on fish reproduction. The purpose of this study was to assess the impact of agricultural pesticides on fish inhabiting a cotton basin in Benin using biometric measurements, plasma sex steroid levels and gonad and liver histology as endpoints.

\section{Materials and methods}

\subsection{Site selection and characterization}

Four sites (Fig. 1) were investigated in northern Benin. The first site, S1, was located in the Pendjari River within the Pendjari National Park and was assigned to be the reference site because it is outside of the cotton-producing basin. This site does not dry up during the dry season and the fishing is regulated. The Pendjari River (length $380 \mathrm{~km}$ ) is a tributary of the Volta River (Ghana) and originates at Pèporiakou (Natitingou, Benin) in the Atacora mountains (Idieti, 2009). It is a freshwater river. The Pendjari River is the natural northern limit of the Pendjari National Park, around which agricultural cultivation is strictly forbidden. The three other sites, S2, S3 and S4, were located along the Alibori River in Sori (Gogounou), Alibori K (Kandi) and Batran (Banikoara), respectively. These three sites never dry and fishing is allowed. The Alibori River (length $338 \mathrm{~km}$ ) is the most important freshwater river crossing in the six largest cotton-producing (Malanville, Karimama, Banikoara, Kandi, Gogounou, Sinendé), with Banikoara being the greatest cotton-producing municipality at $40 \%$ of national production (Gounou, 2009; Agbohessi et al., 2011). Therefore, the Alibori River collects the drainage from most of the agricultural areas in the cotton-producing basin. The river originates in the central plateau of Benin and moves northwards into the Niger River. The three sites were selected based on the expected levels of pesticides while also being representative of the cotton-producing basin rivers in northern Benin. These sites are areas of the river where the tributaries converge and provide sufficient organic matter, where there is a large cotton production with the associated use of different pesticides and where a steep slope to the river allows the drainage of pesticides by leaching of cotton farms. The Alibori River is located within the same geographical area as the Pendjari River and has similar climatic conditions. The study was conducted during the rainy season (September 2010 and 2011), period of flooding with intense use of pesticides in cotton fields, and during the dry season (February 2011 and 2012), period of no agricultural activity but limited use of pesticides to catch fish.

\subsection{Pesticide analysis}

Two stations were selected at each site to collect surface water $\pm 45 \mathrm{~cm}$ deep to determine organochlorine pesticide (OCP) residues. These water samples were collected during two critical periods of the hydrological cycle in northern Benin, i.e., the rainy season and the dry season, using $2 \mathrm{~L}$ green glass bottles that were pre-treated with a sulfochromic mixture (100 g of potassium dichromate, water, and $1.5 \mathrm{~L}$ of sulfuric acid). These samples were stored at $4{ }^{\circ} \mathrm{C}$ and were taken to the Central Laboratory of Control of the Food Safety (Cotonou, Benin) where OCP assays were performed using a GC-MS (gas chromatography-mass spectrometry). The dosage of the OCP was performed in two steps: extraction of OCP from water and quantification.

\subsubsection{Extraction from water}

One liter of water was filtered into an acid washed reagent bottle. C18 solid phase extraction (SPE) cartridges (Waters-Microsep) were conditioned with water, methanol, and water. The samples were then 
allowed to pass through the cartridge and it was dried and eluted with $12 \mathrm{~mL}$ of hexane-diethyl-ether $(85: 15, \mathrm{v} / \mathrm{v})$. The samples were evaporated until dry in nitrogen and were reconstituted in $200 \mu \mathrm{L}$ of methanol before $1 \mu \mathrm{L}$ was injected. A Hewlett Packard (HP 7890) gas chromatography system equipped with an HP 7683 auto injector and an HP 5975 mass selective detector (MSD) (Agilent Technologies, Palo Alto, CA, USA) was used for the chromatographic separation and recording of mass spectra.

\subsubsection{Organochlorine pesticide quantification}

The column temperature increased from 90 to $200{ }^{\circ} \mathrm{C}$ at a rate of $40{ }^{\circ} \mathrm{C} / \mathrm{min}$. The temperature values of the injector and detector were 250 and $200{ }^{\circ} \mathrm{C}$, respectively. A helium carrier gas (high pure helium) was used at a flow rate of $0.84 \mathrm{~mL} / \mathrm{min}$. Samples were injected with a splitless injection mode (Villaverde et al., 2008). Confirmation was performed using selected ion monitoring (SIM). The mass spectra were collected at an electron impact mode of $70 \mathrm{eV}$, and the mass-to-charge ratios $(\mathrm{m} / \mathrm{z})$ of the ions were used for quantification in the SIM mode.

\subsection{Fish sampling}

Immediately following the water sample collection, wild fish (Guinean tilapia, T. guineensis, and African catfish, C. gariepinus) were caught by professional fishermen using gill nets. These species were chosen for the following reasons: i) they are residents and live their whole life cycle in the river; ii) they are sufficiently robust to serve as bio-indicators; iii) they occupy two different trophic levels: Guinean tilapia have a wide trophic spectrum but it is mostly a detritivorous species, whereas the African catfish is omnivorous with a carnivorous trend; and iv) Guinean tilapia reproduce all year, whereas African catfish reproduce only during the rainy season. In addition, these two species are well distributed in the cotton-producing basin rivers of Benin and could be used as indicator species. The total length and weight of each sampled fish were recorded to calculate the Fulton conditioning factor according to the following formula: $\mathrm{K}=100 * \mathrm{~W} / \mathrm{L}^{3}$, where $\mathrm{W}=$ body weight $(\mathrm{g})$ and $\mathrm{L}=$ total length $(\mathrm{cm})$. Each fish was then macroscopically examined to identify external and internal abnormalities, parasites, or lesions.

\subsection{Tissue sampling and processing}

After sampling and measurement, blood samples were taken from the fish with a heparinized $1 \mathrm{~mL}$ injection syringe with adapted $22 \mathrm{G}$ hypodermic needles that were inserted into the caudal vein. In the laboratory, the samples were centrifuged for $15 \mathrm{~min}$ at $4500 \mathrm{rpm}$ and the supernatant was stored at $-20^{\circ} \mathrm{C}$ until a hormone assay was conducted. After blood sampling, the fish were killed by severing the spinal cord anterior to the dorsal fin. A standard necropsy was performed and the liver and gonad weights were recorded to calculate the hepatosomatic index (liver weight/body weight $\times 100$ ) and gonadosomatic index (gonad weight/body weight $\times 100$ ).

\subsection{Sex steroid analyses}

Plasma concentrations of estradiol-17 (E2), 11-keto-testosterone (11-KT) and testosterone $(\mathrm{T})$ were assayed using a radioimmunoassay (RIA) after two extractions with cyclohexane-ethyl acetate according to Fostier and Jalabert (1986) and adapted by Mandiki et al. (2004). All of the samples and standards were assayed in duplicate. Radioactive hormones were purchased from the Amersham Pharmacia (Buckinghamshire, England), T and E2 antibodies were obtained from the Laboratoire d'Hormonologie de Marloie (Belgium), and an anti11-KT was provided by Dr. A. Fostier (INRA, Rennes France). Only one set of assays was performed for each hormone, and the intra-assay coefficients of variation were 4.8, 5.7, and $4.2 \%$ for T, E2 and 11-KT, respectively. The detection limits for the three steroid assays ranged from 5 to $10 \mathrm{pg} / \mathrm{mL}$.

\subsection{Gonad histology}

The mid-sections of the left gonads (male and female) were fixed in a Bouin's solution for up to $72 \mathrm{~h}$ and were then transferred to a $4 \%$ acetic formaldehyde solution. The tissues were then dehydrated through a graded series of methanol, cleared with toluene, and embedded in paraffin.

In males, the testes were cut into a series of $5 \mu \mathrm{m}$ sections and a paraffin section was mounted on every $50 \mu \mathrm{m}$. For the histological analyses, slides were stained with hematoxylin, eosin, and safran (HES) and were examined using light microscopy at a range of magnifications (10-40×). The sections were observed to detect oocytes within the testicular tissue (ovotestis) as an indication of feminization. In feminized testes, the oocyte stages were described and the diameters were measured. Stages of spermatogenesis were determined according to Cek and Yilmaz (2007) and Van Dyk and Pieterse (2008), and quantified by counting cells in a delimited surface under a light microscope. The counting was repeated three times randomly in each testis section.

In females, $5 \mu \mathrm{m}$ sections were mounted on glass slides, stained with trichrome hematoxylin, phloxine B and light green (Tri-green) or with HES (depending on the histological observation objectives) and examined under light microscopy at a range of magnification (10-40x). Six oocyte maturation stages were estimated according to Rinchard and Kestemont (1996) with some modifications. The percentage of each stage was determined for 100 cells per ovary. The diameters of 50 vitellogenic oocytes (stage 4 ) per ovary were measured, considering only those oocytes cut through the nucleus.

For both sexes, a qualitative histopathological assessment was conducted using a multi-headed Olympus light microscope aimed at creating more objective results. The recorded pathologies were also semiquantitatively assessed using a scoring system, which was modified from a protocol by Bernet et al. (1999). For each histological alteration, a score value (indicative of the extent of the lesion throughout the tissue) and an importance factor (indicative of the degree of reversibility of the lesion) were multiplied, and the results for all the alterations identified were then summed to give a gonad index, namely testis index (It) and ovary index (Io), for each male and female specimen, respectively. According to Bernet et al. (1999), the formula used to calculate these indices is

$$
\mathbf{I}_{\text {org }}=\sum_{\text {rp }} \sum_{\text {alt }}\left(\boldsymbol{\alpha}_{\text {org rp alt }} \times \omega_{\text {org rp alt }}\right)
$$

where org $=$ organ (constant), $\mathrm{rp}=$ reaction pattern, alt = alteration, $\alpha=$ score value and $\omega=$ importance factor.

These indices were used to compare the occurrence severity of gonadal histological alterations between the fish from each site. To classify the It and Io results according to the severity of the histological response, the results were evaluated according to a classification system (Van Dyk et al., 2009a,b) based on a scoring scheme by Zimmerli et al. (2007).

Class 1 (index $<10$ ): Normal tissue structure with slight histological alterations.

Class 2 (index 10-25): Normal tissue structure with moderate histological alterations.

Class 3 (index 26-35): Pronounced alteration of organ tissues.

Class 4 (index $>35$ ): Severe alteration of organ tissues.

In addition to the indices calculated for the extent (score value) and pathological importance (importance factor) of the lesions, a further point of interest was the prevalence of histopathological features. The prevalence of every alteration was calculated as a percentage occurrence of an alteration within all of the fish at each site: 
Prevalence of histological alteration $=$ (number of fish with the alteration/total number of fish $) \times \mathbf{1 0 0}$.

\subsection{Liver histology}

A sample (mid-section) of each liver was fixed and treated as a section of the gonads, but was cut at $6 \mu \mathrm{m}$. The sections were mounted on glass slides and stained with HES. To assess the effect of the pollutants on the degree of utilization of glycogen (energy) in the liver in response to this chemical stress, the slides were stained with periodic acid-schiff and hematoxylin safran (PAS + HS). Analyses of the intracellular deposits were performed for selected tissue samples using a Perl's iron stain. A positive reaction indicates the presence of hemosiderin. The procedure for evaluation of liver samples was similar to that used for the gonads.

To compare the overall health status based on the histological lesions, a Total Index $\left(\mathrm{I}_{\mathrm{T}}\right)$ was calculated according to Bernet et al. (1999), by adding up all of the organ indices of individual fish. This index had the general formula:

$\mathrm{I}_{\mathrm{T}}=\sum_{\text {org }} \sum_{\text {alt }} \sum_{\mathrm{rp}}\left(\alpha_{\text {org alt } \mathrm{rp}} \times \omega_{\text {org }}\right.$ alt rp $)$.

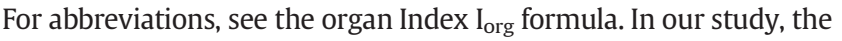
$\mathrm{I}_{\mathrm{T}}$ for each fish was calculated as follows:

$I_{T}=\mathbf{I g}+I_{l}$

where $\mathrm{Ig}=$ the gonad (testis or ovary) index and $\mathrm{I}_{1}=$ the liver index. We can then determine the average Total Index per sex, species and site.

\subsection{Data analysis}

The results were expressed as the mean \pm standard deviation of the mean. For each studied parameter, the data were tested separately for each species. To minimize the effect of gender, the data were also tested separately for males and females. The differences between the means were evaluated with a two-way analysis of variance (ANOVA II) using the season and site as factors. An ANOVA II was followed by Dunnett's comparison as the post hoc test to compare the means for each exposed site with those of the reference site for biometric indices (K, GSI, HSI) and for the plasma sex steroid levels (11-KT, T, E2, E2/T). For the pesticide concentrations, an ANOVA II test was followed by Duncan's multiple range tests because no pesticide was detected at S1. Histological descriptions of tissues were qualitative and Bernet et al. (1999), Zimmerli et al. (2007) and Van Dyk et al. (2009a,b) were used as comparison methods. However, we used an ANOVA II and Dunnett's test for the Total Index. We investigated the relationship between each pesticide concentration and the E2 level for both species by determining the Pearson's correlation coefficient. To determine whether there was a relationship between the plasma E2 levels and the general health of males in both species, we determined the linear correlations between the $\mathrm{E} 2$ and $\mathrm{I}_{\mathrm{T}}$. Calculations were made using Statistica for Windows, version 5.0 Software. p value of 0.05 or less was considered significant. For means expressed in percentages, a statistical analysis dataset was log transformed $(\log [\mathrm{x}+1])$ for normalization.

\section{Results}

\subsection{Pesticide loads}

None of the detected pesticides at the contaminated sites were detected at the reference site, regardless of the season (Table 1). The endosulfan was by far the most abundant OCP detected at the S2 to S4 sites. For all of sites belonging to the Alibori River, the levels measured during the rainy season were significantly higher than those found during the dry season $(p<0.05)$, with significantly higher values observed upstream than downstream in the river during the rainy season. Unlike endosulfan, heptachlor was detected in higher concentrations during the dry season (almost 3 -fold) than during the flooding period $(\mathrm{p}<0.05$ ). With the exception of S4 during the dry season, the levels of heptachlor significantly increased from upstream to downstream: o, $\mathrm{p}^{\prime}$-DDT, lindane and dieldrin were not detected, even at the contaminated sites. The DDE/DDT ratio was greater than 1 in all contaminated sites for both seasons.

\subsection{Biometric indices}

\subsubsection{Length, weight and condition factor}

Selected fish were sexually mature. As shown in Table 2, whatever the season and species, the average total length of fish at each polluted site of Alibori River was similar to that obtained at the reference site ( $\mathrm{p}>$ 0.05 ), except for Guinean tilapia in S3 during the dry season, for which the length was greater than in S1, and for African catfish in S4, for which it was lower than in $\mathrm{S} 1$ whatever the season $(\mathrm{p}<0.05)$. Whatever the species, the fish length did not vary with the season except for African catfish in S4, where the value obtained in the dry season was higher than that in the rainy season $(\mathrm{p}<0.05)$. The fish weight at each site of the Alibori River, whatever the season and the species, was lower than that of S1, with very low values in S4. These weights were higher in the rainy season than in the dry season, except for Guinean tilapia in S4 and African catfish in S3 and S4.

Table 1

OCP residue concentrations $(\mu \mathrm{g} / \mathrm{L})$ in surface water samples from Pendjari River $(\mathrm{S} 1)$ and Alibori River $(\mathrm{S} 2, \mathrm{~S} 3, \mathrm{~S} 4)$. Values are expressed as mean \pm standard error $(\mathrm{n}=2)$.

\begin{tabular}{|c|c|c|c|c|c|c|c|c|}
\hline \multirow[t]{2}{*}{ Organochlorine pesticides } & \multicolumn{4}{|c|}{ Flooding season } & \multicolumn{4}{|c|}{ Dry season } \\
\hline & S1 & $\mathrm{S} 2$ & S3 & S4 & $\mathrm{S} 1$ & $\mathrm{~S} 2$ & S3 & S4 \\
\hline$o, p^{\prime}-D D T$ & $<$ LD & $<$ LD & $<$ LD & $<$ LD & $<\mathrm{LD}$ & $<$ LD & $<\mathrm{LD}$ & $<\mathrm{LD}$ \\
\hline $\mathrm{p}, \mathrm{p}^{\prime}-\mathrm{DDT}$ & $<\mathrm{LD}$ & $<\mathrm{LD}$ & $<\mathrm{LD}$ & $0.105 \pm 0.018^{A}$ & $<\mathrm{LD}$ & $<\mathrm{LD}$ & $<\mathrm{LD}$ & $0.065 \pm 0.001^{\mathrm{B}}$ \\
\hline $\mathrm{o}, \mathrm{p}^{\prime}-\mathrm{DDE}$ & $<\mathrm{LD}$ & $0.167 \pm 0.037^{\mathrm{a}}$ & $0.191 \pm 0.011^{\mathrm{a}}$ & $0.089 \pm 0.004^{\mathrm{bA}}$ & $<\mathrm{LD}$ & $0.176 \pm 0.031$ & $0.139 \pm 0.023$ & $0.174 \pm 0.045^{\mathrm{B}}$ \\
\hline $\mathrm{p}, \mathrm{p}^{\prime}-\mathrm{DDE}$ & $<\mathrm{LD}$ & $0.128 \pm 0.009^{\mathrm{aA}}$ & $0.095 \pm 0.007^{\mathrm{a}}$ & $0.178 \pm 0.001^{\mathrm{b}}$ & $<\mathrm{LD}$ & $0.074 \pm 0.006^{\mathrm{aB}}$ & $0.083 \pm 0.004^{\mathrm{a}}$ & $0.137 \pm 0.018^{\mathrm{b}}$ \\
\hline $0, \mathrm{p}^{\prime}-\mathrm{DDD}$ & $<\mathrm{LD}$ & $0.069 \pm 0.011$ & $0.093 \pm 0.023$ & $0.086 \pm 0.005$ & $<\mathrm{LD}$ & $<$ LD & $<\mathrm{LD}$ & $<\mathrm{LD}$ \\
\hline $\mathrm{p}, \mathrm{p}^{\prime}-\mathrm{DDD}$ & $<\mathrm{LD}$ & $0.094 \pm 0.002$ & $<\mathrm{LD}$ & $0.076 \pm 0.003$ & $<\mathrm{LD}$ & $<$ LD & $<\mathrm{LD}$ & $0.084 \pm 0.006$ \\
\hline DDE/DDT & - & $>1$ & $>1$ & $>1$ & - & $>1$ & $>1$ & $>1$ \\
\hline$\sum$ endosulfan & $<\mathrm{LD}$ & $8.22 \pm 0.90^{\mathrm{aA}}$ & $8.82 \pm 1.93^{\mathrm{aA}}$ & $13.83 \pm 1.53^{\mathrm{bA}}$ & $<\mathrm{LD}$ & $2.92 \pm 1.27^{\mathrm{aB}}$ & $3.35 \pm 0.26^{\mathrm{abB}}$ & $3.72 \pm 0.09^{\mathrm{bB}}$ \\
\hline Lindane & $<$ LD & $<\mathrm{LD}$ & $<\mathrm{LD}$ & $<\mathrm{LD}$ & $<$ LD & $<\mathrm{LD}$ & $<\mathrm{LD}$ & $<\mathrm{LD}$ \\
\hline Dieldrin & $<\mathrm{LD}$ & $<\mathrm{LD}$ & $<\mathrm{LD}$ & $<$ LD & $<\mathrm{LD}$ & $<\mathrm{LD}$ & $<$ LD & $<\mathrm{LD}$ \\
\hline Heptachlor & $<\mathrm{LD}$ & $0.450 \pm 0.226^{\mathrm{aA}}$ & $0.495 \pm 0.092^{\mathrm{aA}}$ & $0.580 \pm 0.127^{\mathrm{bA}}$ & $<\mathrm{LD}$ & $1.444 \pm 0.612^{\mathrm{aB}}$ & $1.502 \pm 0.573^{\mathrm{bB}}$ & $1.323 \pm 0.190^{\mathrm{cB}}$ \\
\hline
\end{tabular}

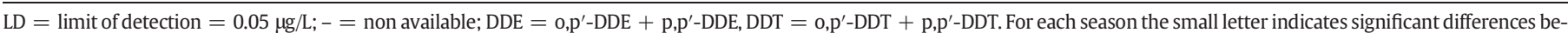
tween sites $(p<0.05)$. For each site the capital letter indicates significant differences between seasons $(p<0.05)$. 
Table 2

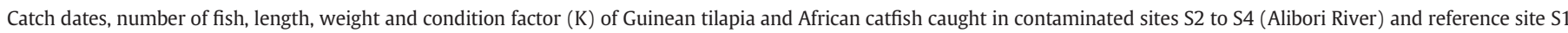
(Pendjari River).

\begin{tabular}{|c|c|c|c|c|c|c|c|c|c|c|c|}
\hline \multirow[t]{2}{*}{ Species } & \multirow[t]{2}{*}{ Sites } & \multicolumn{5}{|c|}{ Flooding season } & \multicolumn{5}{|l|}{ Dry season } \\
\hline & & Catch dates & $\mathrm{n}$ & $\begin{array}{l}\text { Length } \\
(\mathrm{cm})\end{array}$ & $\begin{array}{l}\text { Weight } \\
\text { (g) }\end{array}$ & $\mathrm{K}$ & Catch dates & $\mathrm{n}$ & $\begin{array}{l}\text { Length } \\
(\mathrm{cm})\end{array}$ & $\begin{array}{l}\text { Weight } \\
\text { (g) }\end{array}$ & K \\
\hline \multirow[t]{4}{*}{ Guinean tilapia } & S1 & $\begin{array}{l}18-09-2011 \\
10-11-2012\end{array}$ & 20 & $22.8 \pm 4.77^{\mathrm{aA}}$ & $235.86 \pm 8.32^{\mathrm{aA}}$ & $1.99 \pm 0.25^{\mathrm{aA}}$ & 28-02-2012 & 15 & $21.9 \pm 6.8 \mathrm{I}^{\mathrm{aA}}$ & $100.83 \pm 8.9^{\mathrm{aB}}$ & $0.96 \pm 0.18^{\mathrm{aB}}$ \\
\hline & $\mathrm{S} 2$ & $20-09-2010$ & 32 & $21.5 \pm 3.9^{\mathrm{aA}}$ & $112.3 \pm 3.5^{\mathrm{bA}}$ & $1.13 \pm 0.20^{\mathrm{bA}}$ & 28-02-2011 & 19 & $22.6 \pm 3.9^{\mathrm{aA}}$ & $70.41 \pm 12.1^{\mathrm{bB}}$ & $0.61 \pm 0.21^{\mathrm{aB}}$ \\
\hline & S3 & 09-11-2012 & 32 & $23.1 \pm 2.93^{\mathrm{aA}}$ & $155.31 \pm 1.76^{\mathrm{bA}}$ & $1.26 \pm 0.03^{\mathrm{bA}}$ & & 29 & $25.1 \pm 4.7^{\mathrm{bA}}$ & $75.90 \pm 9.8^{\mathrm{bB}}$ & $0.48 \pm 0.24^{\mathrm{bB}}$ \\
\hline & S4 & & 36 & $19.1 \pm 3.2^{\mathrm{aA}}$ & $42.5 \pm 3.41^{\mathrm{cA}}$ & $0.61 \pm 0.14^{\mathrm{cA}}$ & & 36 & $18.3 \pm 4.7^{\mathrm{aA}}$ & $31.87 \pm 9.3^{\mathrm{cA}}$ & $0.52 \pm 0.17^{\mathrm{bA}}$ \\
\hline \multirow[t]{4}{*}{ African catfish } & $\mathrm{S} 1$ & $\begin{array}{l}18-09-2011 \\
10-11-2012\end{array}$ & 44 & $46.0 \pm 7.7^{\mathrm{aA}}$ & $1284.84 \pm 4.51^{\mathrm{aA}}$ & $1.32 \pm 0.08^{\mathrm{aA}}$ & 28-02-2012 & 33 & $45.71 \pm 9.1^{\mathrm{aA}}$ & $1031.47 \pm 21.9^{\mathrm{aB}}$ & $1.08 \pm 0.11^{\mathrm{aA}}$ \\
\hline & S2 & 20-09-2010 & 32 & $47.5 \pm 10.1^{\mathrm{aA}}$ & $1050.28 \pm 7.9^{\mathrm{bA}}$ & $0.98 \pm 0.01^{\mathrm{aA}}$ & $28-02-2011$ & 18 & $48.01 \pm 7.7^{\mathrm{aA}}$ & $841.02 \pm 7.2^{\mathrm{bB}}$ & $0.76 \pm 0.07^{\mathrm{aA}}$ \\
\hline & S3 & 09-11-2012 & 32 & $45.3 \pm 6.98^{\mathrm{aA}}$ & $911.0 \pm 5.9^{\mathrm{bA}}$ & $0.97 \pm 0.07^{\mathrm{aA}}$ & & 16 & $46.71 \pm 9.0^{\mathrm{aA}}$ & $825.5 \pm 6.9^{\mathrm{bA}}$ & $0.81 \pm 0.31^{\mathrm{aA}}$ \\
\hline & S4 & & 38 & $35.0 \pm 3.9^{\mathrm{bA}}$ & $373.01 \pm 9.11^{\mathrm{cA}}$ & $0.87 \pm 0.36^{\mathrm{aA}}$ & & 16 & $42.9 \pm 4.6^{\mathrm{bB}}$ & $331.61 \pm 11.1^{\mathrm{cA}}$ & $0.42 \pm 0.17^{\mathrm{bB}}$ \\
\hline
\end{tabular}

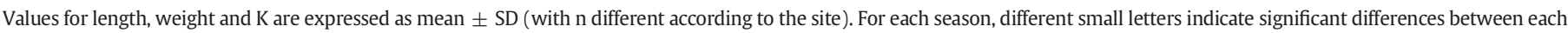

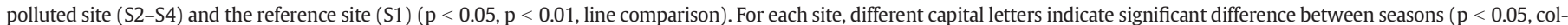
umn comparison).

Significant differences in the K were observed between fish sampled at S1 and those sampled at S2-S4. This is valid only for Guinean tilapia. For African catfish, the difference was only significant between $\mathrm{S} 1$ and S4. In this case, the results for Clarias should be presented as exhibiting a similar tendency as tilapia in $\mathrm{K}$ reduction at polluted sites, although it was not statistically significant. In tilapia, the K values were significantly higher during the rainy season, whereas no significant differences were observed between the flooding and dry periods in African catfish, except at S4.

\subsubsection{Gonadosomatic index (GSI)}

For females, GSI were higher $(\mathrm{p}<0.05)$ at S1 than at S2-S4, whatever the season and species. The same pattern was observed in males during the dry season but not during the rainy season. African catfish developed larger gonads during the rainy season, with a maximal GSI of $10.11 \%$ in females at S1. In Guinean tilapia, the difference between the two seasons was significant only for males in S2, but the trend for both sexes was that the GSI at the rainy season were higher than that at the dry season, with a maximal GSI of $2.76 \%$ in females at S1.
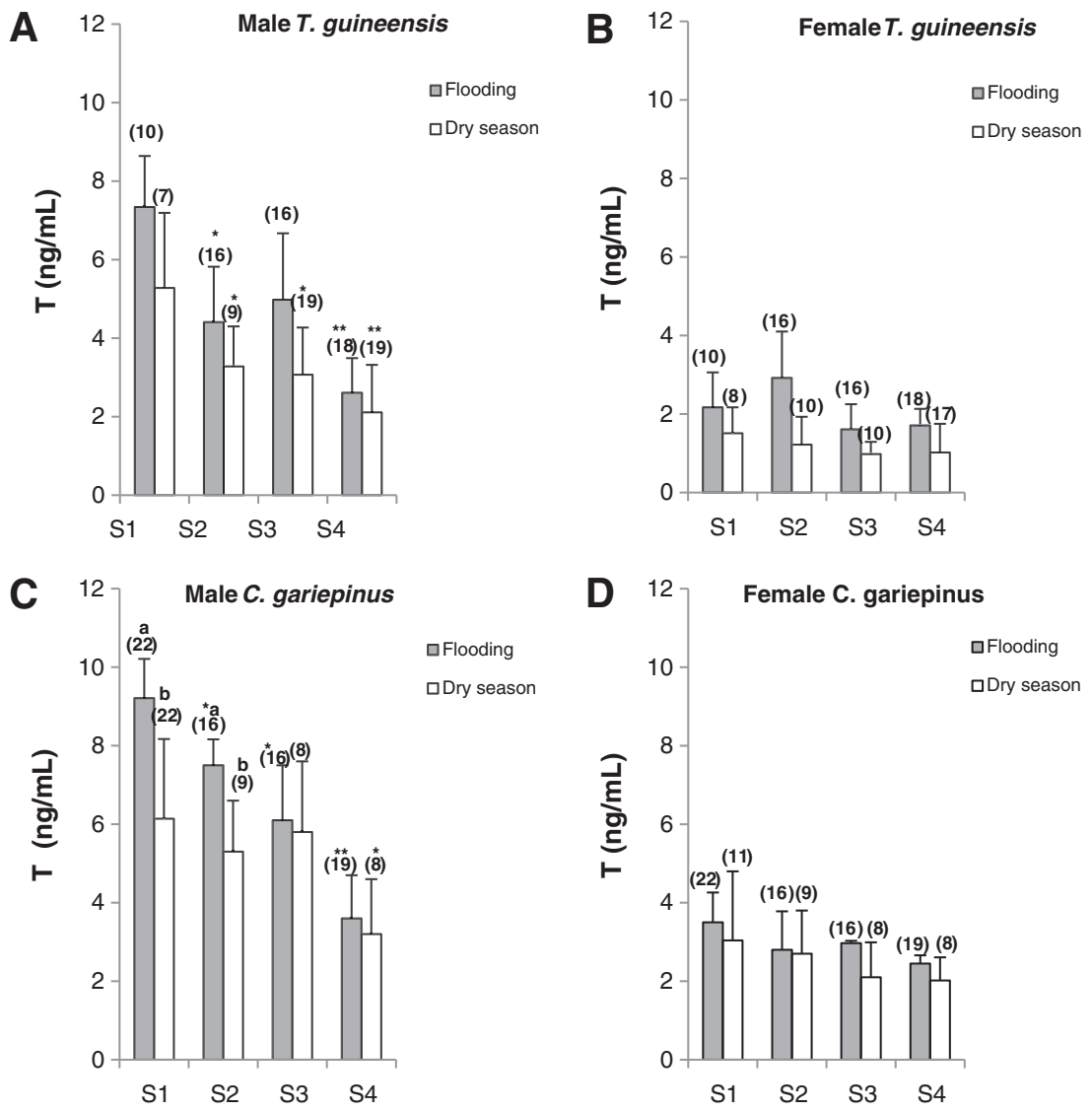

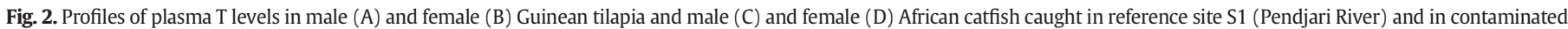

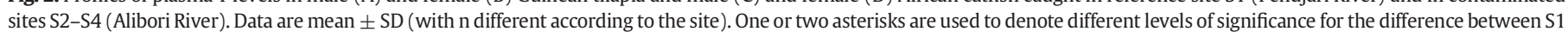
and $\mathrm{S} 2-\mathrm{S} 4\left({ }^{*} \mathrm{p}<0.05,{ }^{*} \mathrm{p}<0.01\right)$. In the same way, different letters denote significant difference $(\mathrm{p}<0.05)$ between seasons at each site. 


\subsubsection{Hepatosomatic index (HSI)}

With few exceptions, the HSI values of the fish sampled at S1 were lower ( $p<0.05)$ than in fish from the contaminated sites, regardless of the season, species and sex. In Guinean tilapia, the highest HSI values were recorded at $\mathrm{S} 4$ for both sexes and seasons, with values ranging from $1.74 \pm 0.56 \%$ in males (dry season) and $2.34 \pm 0.17 \%$ in females (dry season) $(\mathrm{p}<0.01)$. In African catfish, the highest HSI $(\mathrm{p}<0.05)$ was observed at the Alibori River sites (S2, S3 and S4), with the exception of males at S3 during the flooding season and for females at S2 during the flooding and dry seasons.

\subsection{Levels of plasma sex steroids}

\subsubsection{Plasma concentrations of testosterone ( $T$ )}

Whatever the season, plasma T levels were significantly lower in male Guinean tilapia captured in Alibori River sites S2, S3 ( $p<0.05)$ and S4 $(p<0.01)$ than in the reference site S1, except for S3 in the flooding period where the difference was not significant (Fig. 2A). The lowest $\mathrm{T}$ values were found in males from $\mathrm{S} 4$ both during the rainy season $(2.61 \pm 0.88 \mathrm{ng} / \mathrm{mL})$ and the dry season $(2.11 \pm 1.21 \mathrm{ng} / \mathrm{mL})$. In females, $\mathrm{T}$ levels did not significantly differ between the Alibori river and reference sites (Fig. 2B).

In male African catfish (Fig. 2C), the T levels were lower in fish from the Alibori River sites compared to fish from the reference site, particularly at S2, S3 $(\mathrm{p}<0.05)$ or S4 $(\mathrm{p}<0.01)$ during the rainy season or at S4 $(p<0.05)$ during the dry season. The T values in males during the rainy season were significantly higher than those found in the dry season at sites S1 and S2 ( $\mathrm{p}$ 0.05). In females (Fig. 2D), the T values did not significantly differ regardless of the site or season.

\subsubsection{Plasma concentrations of 11-ketotestosterone (11-KT)}

In male Guinean tilapia (Fig. 3A) captured in the Alibori River, 11-KT values were significantly reduced during the rainy season in sites S2 and
S4 $(\mathrm{p}<0.05)$. During the dry season, such reduction in plasma 11-KT was observed only in fish from site $S 4(p<0.05)$. The lowest 11-KT values were found in males captured at site $\mathrm{S4}$, both during the rainy season $(4.02 \pm 1.11 \mathrm{ng} / \mathrm{mL})$ and the dry season $(3.13 \pm 1.14 \mathrm{ng} / \mathrm{mL})$. In contrast to males, 11-KT levels in females (Fig. 3B) captured in the Alibori River sites did not significantly differ from those of fish collected at the reference site, whatever the season.

As for Guinean tilapia, 11-KT levels were lower in male African catfish (Fig. 3C) captured in the Alibori River sites compared to those found in fish from reference site, differences being significant for fish from S3 $(5.68 \pm 0.53 \mathrm{ng} / \mathrm{mL})$ and S4 $(4.71 \pm 0.51 \mathrm{ng} / \mathrm{mL})$ during the rainy season or those from S3 $(2.62 \pm 1.91 \mathrm{ng} / \mathrm{mL})$ and S4 $(3.81 \pm$ $1.34 \mathrm{ng} / \mathrm{mL}$ ) during the dry season $(\mathrm{p}<0.05)$. Similarly, 11-KT levels were significantly lower in female African catfish (Fig. 3D) captured in the Alibori River sites than in fish from reference site $(p<0.05)$, except in S2 during the flooding period.

\subsubsection{Plasma concentrations of estradiol-17ß (E2) and E2/T ratio}

In contrast to 11-KT and T, E2 levels (Fig. 4A) were significantly elevated $(p<0.01)$ in male Guinean tilapia captured in the Alibori River site releases compared to levels in fish from to the reference site during the two seasons. The highest values were obtained in fish from site S4 during the rainy season $(1.79 \pm 0.23 \mathrm{ng} / \mathrm{mL})$ and the dry season $(1.37 \pm$ $0.34 \mathrm{ng} / \mathrm{mL}$ ). The same trend of elevation was also observed in females (Fig. 4B) captured in Alibori River sites but significant differences were calculated only for fish from sites S3 and S4 $(\mathrm{p}<0.05)$ during the rainy season.

As for Guinean tilapia, E2 levels were also higher in male catfish (Fig. 4C) captured in Alibori River, reaching the highest values in sites $\mathrm{S} 2(2.98 \pm 0.87 \mathrm{ng} / \mathrm{mL})$ and S4 $(3.21 \pm 0.61 \mathrm{ng} / \mathrm{mL})$ during the rainy season $(\mathrm{p}<0.01)$ and dry season $(\mathrm{p}<0.05)$, respectively. Similarly to males, significantly elevated E2 levels were observed in females from the polluted river (Fig. 4D) with highest levels in fish from
A
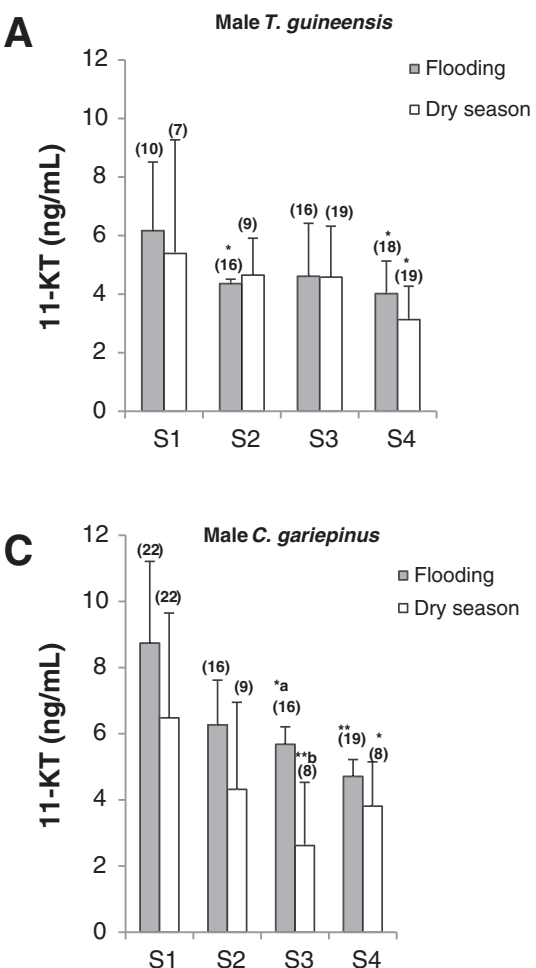

B
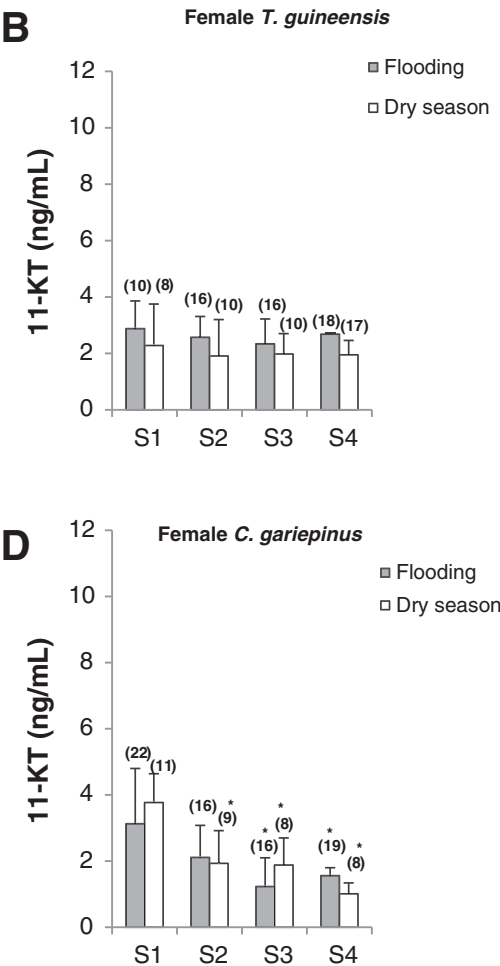

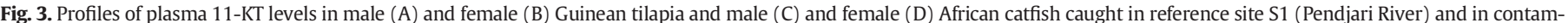

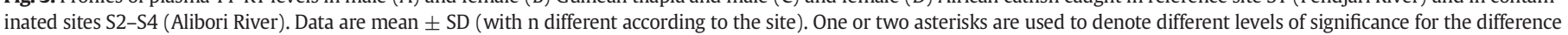
between S1 and S2-S4 ( $\left.{ }^{*} \mathrm{p}<0.05,{ }^{* *} \mathrm{p}<0.01\right)$. In the same way, different letters denote significant difference $(\mathrm{p}<0.05)$ between seasons at each site. 

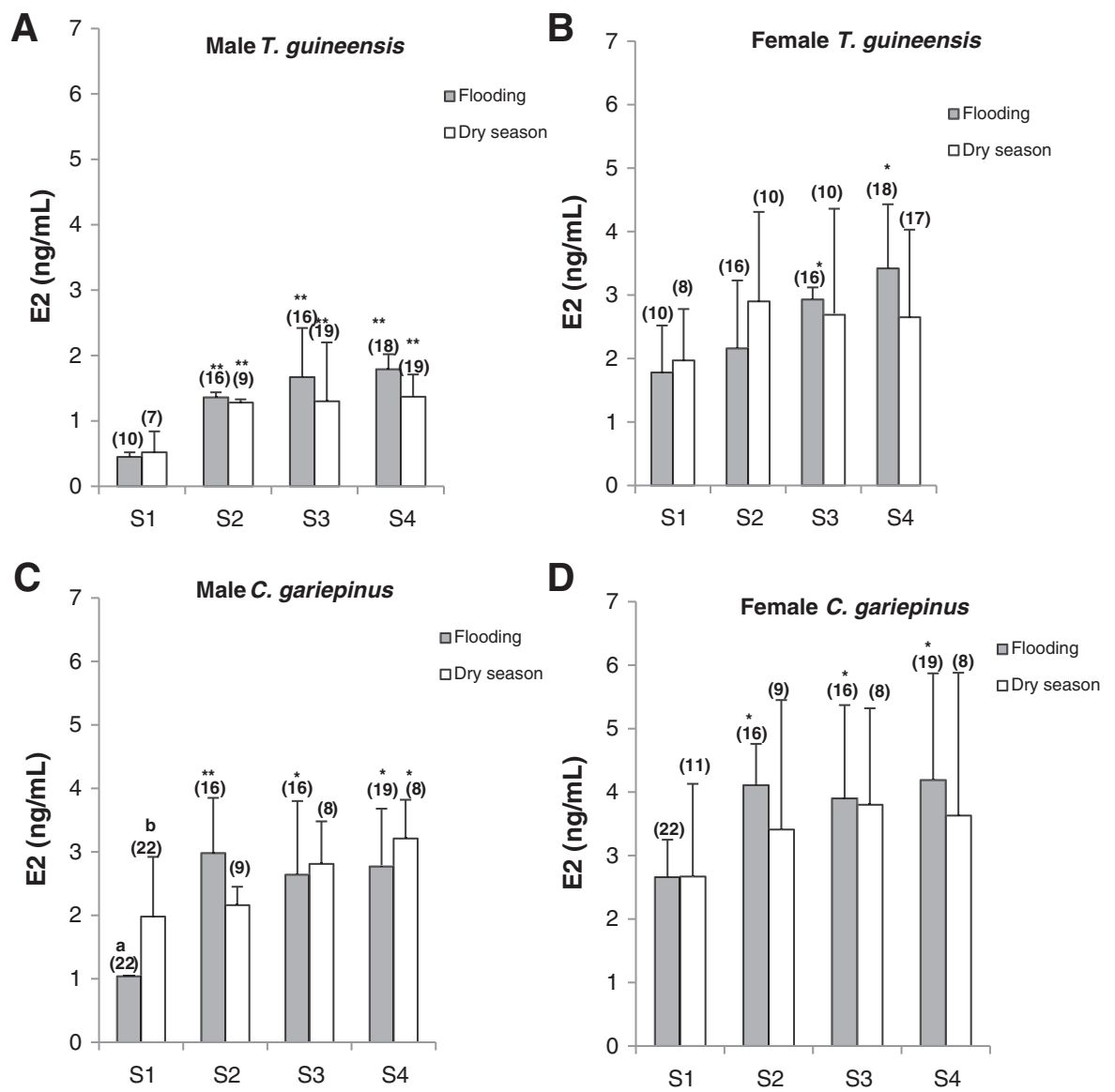

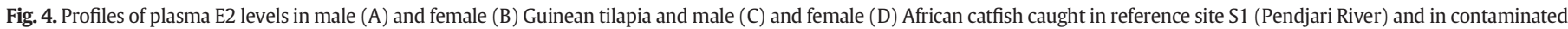

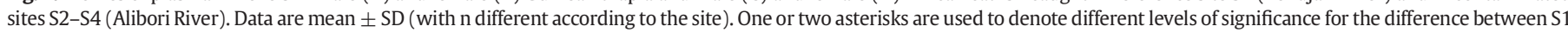
and S2-S4 $\left({ }^{*} \mathrm{p}<0.05,{ }^{* *} \mathrm{p}<0.01\right)$. In the same way, different letters denote significant difference $(\mathrm{p}<0.05)$ between seasons at each site.

site S2 $(4.11 \pm 0.65 \mathrm{ng} / \mathrm{mL})$ during the rainy season $(\mathrm{p}<0.05)$. During the dry season, E2 levels did not differ significantly whatever the site, although a trend of increase was observed for fish caught at Alibori River.

The effect of agricultural pesticide releases on the production of sex steroids was also evaluated using an E2/T ratio. The plasma E2/T ratios in males and females of both fish species were higher at S4 than at S1 $(\mathrm{p}<0.05)$ during both seasons.

\subsection{Gonad histology}

\subsubsection{Males}

3.4.1.1. Maturation stages. Sections of Guinean tilapia testis exhibited all stages of spermatogenesis at all sites but not in all fish during the dry season. Spermatids and spermatozoa were poorly represented $(0.3-$ $1.7 \%$ and $3.0-7.0 \%$, respectively) in the testes of fish from the contaminated sites compared to those from the reference site $(4.8 \%$ and $45.2 \%$, respectively). The spermatozoa were found in only $11.1,11.1$ and $10 \%$ of the males sampled at S2, S3 and S4, respectively, compared with $57.1 \%$ of the fish sampled at S1. Similar results were observed during the rainy season, such that all stages were represented at all sites but not in all fish. All fish from all sites released sperm, but those from the contaminated sites contained low levels of spermatids and spermatozoa (0.1-0.6\% and $12.7-26.3 \%$, respectively) compared with fish from S1 (9.9 and 61.6\%, respectively).
In African catfish, the spermatids and spermatozoa were not present in the testes of fish sampled during the dry season, regardless of the site. The proportion of type II spermatocytes (Scyt II) was lower in the fish from the Alibori River sites (17.0-24.0\%) compared with those of the reference site (40.0\%). Only 25 to $66.7 \%$ of males from S2-S4 reached the Scyt II stage, compared with $98.3 \%$ of the males sampled in S1. Contrarily to the dry season, all stages of spermatogenesis were recorded in all sites during the flooding period, although not in all fish sampled. The proportion of spermatozoa in testes of fish from contaminated sites (11.4-21.3\%) was significantly lower than in those from reference site (78.2\%). All fish from S1 were releasing sperm versus $87.5,75$ and $77.8 \%$ in S2, S3 and S4, respectively.

3.4.1.2. The prevalence of histological alterations in the testes. Alterations of the testes are exhibited in Fig. 5. The fish (Guinean tilapia and African catfish) sampled at S1 displayed the lowest percentages of gonad alterations (2-6 alterations), whereas the fish sampled at S4 displayed the highest (8-9 alterations). The highest degree of histological alterations was observed for both species and for almost all sites during the rainy season. Regressive changes (i.e., fibrosis, necrosis, vacuolation of the testicular parenchyma, presence of immature cells in the lobular lumen, detachment of lobe basal membrane, disorganization of lobular and cyst structures, and presence of foam cells in the lobe lumen) were found to be more prevalent in both species and seasons from all of the sampling sites, compared with any of the other reaction patterns. For all of the sampling sites and seasons, with the exception 

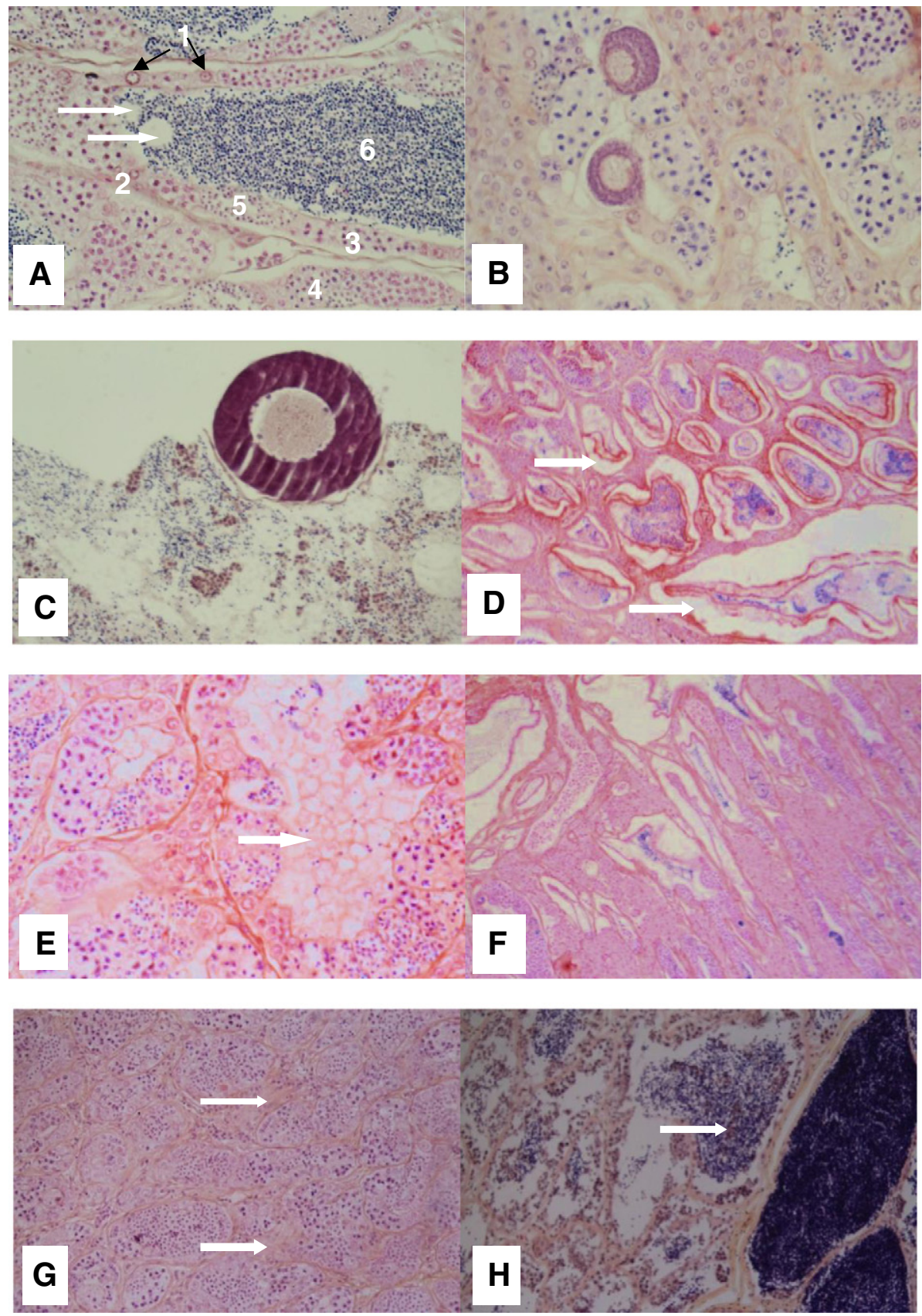

Fig. 5. Light micrographs of testis sections (stained with HES) of: (A) African catfish from S1 showing infiltration of adipocytes (arrows) and the different stages of spermatogenesis (1) Sg A, (2) Sg B, (3) Scyt I, (4) Scyt II, (5) Spd, and (6) Spz; (B) Guinean tilapia from S3 showing two testicular oocytes; (C) African catfish from S4 showing one testicular oocyte; (D) Guinean tilapia (S4) showing detachment of the basal membrane (arrows); (E) Guinean tilapia (S4) showing foam cells (arrow); (F) Guinean tilapia (S4) showing disorganization of lobular structure; (G) African catfish (S4) showing interstitial fibrosis (arrows); (H) African catfish (S2) showing immature cells in the lobular lumen (arrow). Magnifications: 10× (D, F, G), 20× (A, C, E, $\mathrm{H}), 40 \times(B)$.

Table 3

Diameters $(\mu \mathrm{m})$ of testicular oocytes and vitellogenic oocytes in males and females of Guinean tilapia and African catfish according to the season and site.

\begin{tabular}{|c|c|c|c|c|c|c|c|c|c|}
\hline \multirow[t]{2}{*}{ Oocytes } & \multirow[t]{2}{*}{ Species } & \multicolumn{2}{|l|}{ S1 } & \multicolumn{2}{|l|}{ S2 } & \multicolumn{2}{|l|}{ S3 } & \multicolumn{2}{|l|}{ S4 } \\
\hline & & Flooding & Dry season & Flooding & Dry season & Flooding & Dry season & Flooding & Dry season \\
\hline \multirow[t]{2}{*}{ Testicular oocytes } & Guinean tilapia & - & - & $91.3 \pm 8.8^{\mathrm{a}}$ & $75.0 \pm 7.1^{\mathrm{a}}$ & $90.0 \pm 3.5^{a}$ & $102.5 \pm 24.8^{\mathrm{a}}$ & $91.5 \pm 19.1^{\mathrm{a}}$ & $81.3 \pm 5.3^{a}$ \\
\hline & African catfish & 45.0 & - & $106.8 \pm 19.5^{\mathrm{a} *}$ & $118.0 \pm 37.1^{\mathrm{b}}$ & $116.3 \pm 37.1^{* \mathrm{~b}}$ & $128.8 \pm 33.6^{\mathrm{b}}$ & $135.0 \pm 63.6^{* * \mathrm{~b}}$ & $100.0 \pm 3.5^{\mathrm{b}}$ \\
\hline \multirow[t]{2}{*}{ Vitellogenic oocytes } & Guinean tilapia & $368.2 \pm 28.6^{\mathrm{a}}$ & $229.4 \pm 34.8$ & $278.5 \pm 68.8^{* a}$ & $175.0 \pm 77.1^{*}$ & $289.7 \pm 53.5^{* a}$ & $182.5 \pm 22.5^{*}$ & $261.1 \pm 17.1^{* \mathrm{a}}$ & $159.3 \pm 35.3^{*}$ \\
\hline & African catfish & $627.1 \pm 18.3^{\mathrm{b}}$ & - & $487.5 \pm 19.2^{* \mathrm{~b}}$ & - & $509.4 \pm 8.9^{* \mathrm{~b}}$ & - & $375.0 \pm 87.4^{* \mathrm{~b}}$ & - \\
\hline
\end{tabular}

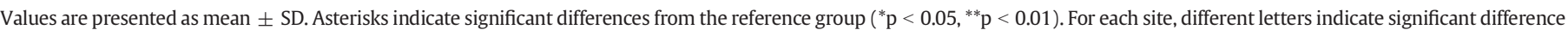
between species $(\mathrm{p}<0.05)$. - no testicular oocytes or vitellogenic oocytes. 
of S3 during flood recession, vacuolation was more prevalent than any of the other types of identified alterations. With the exception of the reference site, vacuolation was present in more than $60 \%$ of the testis sampling from each contaminated site. The cyst disorganization was more frequently observed in African catfish sampled at the contaminated sites than in Guinean tilapia (only found in $30 \%$ of the tissue during the flooding period at S4). The presence of testicular oocytes (previtellogenic oocytes) was detected in fish sampled at the Alibori River sites, ranging from 12.5 to $40 \%$ of the Guinean tilapia and from 25 to $50 \%$ of the African catfish; the highest prevalence was recorded at S4 for both species. One case of a testicular oocyte was also identified in African catfish sampled in the Pendjari River during the rainy season.

3.4.1.3. Semi-quantitative analysis. The testis alterations observed in the fish sampled at the contaminated sites were much more pronounced than those found in fish from the reference site. During the rainy season, the testis alterations reached a class of 3 ( $26 \leq$ It $\leq 35$ ) in Guinean tilapia sampled at the contaminated sites, compared to at S1 where they reached class $2(10 \leq$ It $\leq 25)$. In African catfish, testis alterations
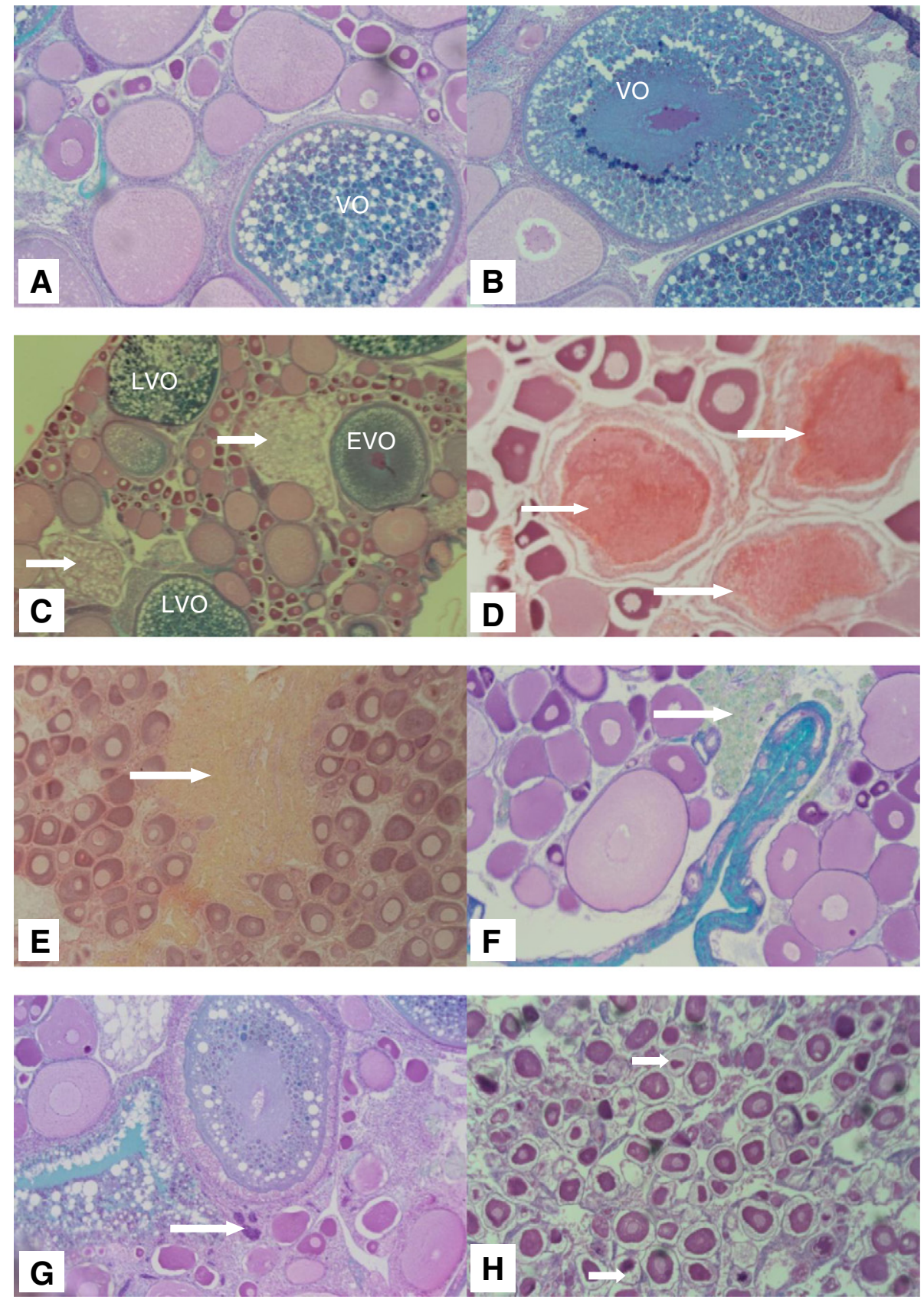

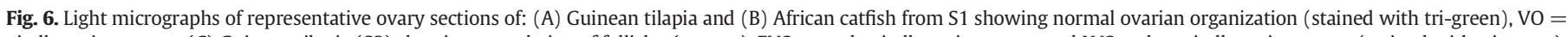

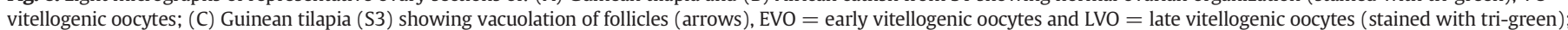

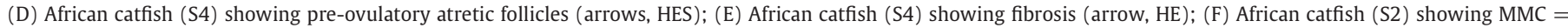

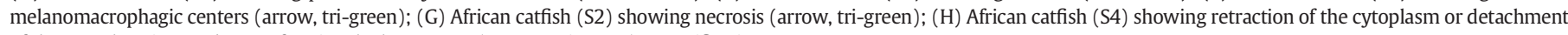
of the cytoplasmic membrane of perinucleolar oocytes (arrows, tri-green). Magnification: 10×. 
reached class 4 (It > 35) in fish from S4 and class 3 in S2 and S3, compared to $\mathrm{S} 1$ where they were only classified as class 2 . During the dry season, pronounced class 3 alterations of testicular tissue were recorded only in Guinean tilapia from S4 while class 3 was reached in African catfish from all contaminated sites. In males exhibiting testicular oocytes, it was verified that the oocyte diameter was higher in African catfish than in Guinean tilapia ( $\mathrm{p}<0.05$ ), regardless of site and season, except for S2. For both species, no significant differences of oocyte diameters were observed between seasons $(p>0.05)$ (Table 3).

\subsubsection{Females}

3.4.2.1. Maturation stages. Ovary sections of female Guinean tilapia sampled during the dry season indicated the presence of all stages of oogenesis in all sites with a marked preponderance of the perinucleolar stage (59.7-72.8\%). Higher rates of oocytes at cortical alveolar (14.1-20.1\%) and early vitellogenic (12.9-17.1\%) stages and lower rates of late vitellogenic oocyte stages (2.95-6.0\%) were observed in fish sampled in contaminated sites compared to the reference one. During the dry season, ovaries contained very few oocytes exceeding the late vitellogenic stage. During floods, all stages were present in the ovaries of Guinean tilapia sampled at all sites, with a marked preponderance of perinucleolar oocytes (55.1-56.6\%). A higher proportion of oocytes at the cortical alveolar (16.9-18.2\%) and early vitellogenic (16.3$18.8 \%$ ) stages, and a lower proportion of late vitellogenic oocytes (5.2$8.7 \%$ ) and few oocytes in final maturation were recorded in fish from Alibori River sites compared to those sampled in S1.

In African catfish, ovary sections from fish sampled during the dry season indicate the presence of the first three stages of oocyte development with a higher proportion of perinucleolar oocytes (71.1-78.5\%) and lower proportions of cortical alveolar oocytes (11.8-16.1\%) and early vitellogenic oocytes (9.7-13.7\%) in fish from contaminated sites compared to those from the reference site. On the other hand, during the flooding period, the first four stages were observed in ovaries from fish sampled in S2 to S4, with a rather low percentage of late vitellogenic oocytes (6.1-7.9\%) and very few stage 5 and 6 oocytes, in comparison with those from the reference site.

3.4.2.2. Prevalence of ovarian alterations. Five types of alterations, all classified as regressive changes (RC) were identified in Guinean tilapia and African catfish females (Fig. 6). These are necrosis, fibrosis, preovulatory atretic follicles, melano-macrophage centers (MMC), vacuolation and detachment of the cytoplasmic membrane in perinucleolar oocytes. Regardless of the species and season, fish from S1 displayed a lowest number of alterations (0-4 damage). The most prevalent alteration in fish sampled at S1 was the presence of MMC (33.3\%), which was observed in African catfish during the dry season. Necrosis was also identified in $16.7 \%$ of African catfish sampled during both seasons. Regardless of the species and season, all of the alteration types described above were more frequently found in S2-S4. Among the highimportance alterations (factor 3), the atretic pre-ovulatory follicles were the most prevalent in both species, with higher percentages during the rainy season in fish from contaminated sites.

3.4.2.3. Semi-quantitative analysis of ovarian alterations. The same classes of ovarian alterations (class 2 ) were determined at all sites, regardless of the species and season, with the exception of Guinean tilapia that were sampled at S1 during the dry season and exhibited fewer histological alterations. However, a more detailed analysis showed that Io of African catfish captured at contaminated sites were closer to class 3 than Io at the reference site, whatever the season. For both species, Io of fish from polluted sites was higher than that of S1. A comparison between the testes and ovary alterations in both species at each site indicated that the testis structures were more impacted than the ovarian structures.
For both species, the vitellogenic oocytes of fish sampled in contaminated sites S2-S4 were significantly smaller $(p<0.05)$ than their counterparts in fish captured in the reference site (Table 3 ). As expected, vitellogenic oocytes of Guinean tilapia were larger during the rainy season. In addition, they were smaller than those of African catfish (Table 3).

\subsection{Liver histology}

\subsubsection{Prevalence of liver alterations}

In males, the highest numbers of liver alterations (13 alterations) were observed in Guinean tilapia sampled at S4 during the rainy season, in African catfish sampled at S2 during the rainy season, and at S4 during the dry season (Figs. 7 and 8). Fish sampled from the Pendjari River displayed the lowest number of liver alterations ( $\leq 6$ alterations). Regressive changes were found to be more prevalent in both species from all of the sampling sites, compared to any other of the reaction patterns. The MMC and glycogen depletion were highly present in more than 42.9 and $33.3 \%$ of liver sampling, respectively, regardless of the species and season. In all of the samples, the MMC were, in most cases (52\%), characterized by multiple small structures dispersed throughout the liver parenchyma (Fig. 8F).

In females (Figs. 7 and 8), the highest number of liver alterations was observed in African catfish at S3 and S4 during the rainy season. The fish sampled at $\mathrm{S} 1$ displayed the lowest number of alterations ( $\leq 7$ alterations). Regressive changes were more prevalent than progressive ones. MMC, simple cell necrosis and glycogen depletion, were present at all sites, regardless of the species and season. As a general statement, liver alterations in males were much more pronounced than in females. There was a higher prevalence of liver alterations at S2-S4 than at S1, for both species and both sexes.

\subsubsection{Semi-quantitative analysis}

Liver index $\left(\mathrm{I}_{1}\right)$ of male African catfish was higher in all contaminated sites, reaching the class $4\left(I_{l} \geq 35\right)$ while $I_{1}$ of fish from $S 1$ remained in class $2\left(10 \leq \mathrm{I}_{1} \leq 25\right)$. In general, $\mathrm{I}_{1}$ was higher during the rainy season than during the dry season. In Guinean tilapia, only males sampled in S2 and S3 during the rainy season and in S4 during the dry season reached the class 4 . As in males, $\mathrm{I}_{1}$ of female African catfish was higher during the rainy season than during the dry one, the class 4 being reached only in S4 during the flood, while $\mathrm{I}_{1}$ of females sampled in the other contaminated sites never exceeded class 3. Similar observations were done for Guinean tilapia, with $\mathrm{I}_{1}$ of females in class 2, except in S4 (class 3). In fish sampled in the Pendjari River (S1), $\mathrm{I}_{1}$ was similar in males and females.

\subsection{Overall health status of fish}

The total index was calculated for both species, sex and season for all sampling sites (Table 4) in order to determine and compare the general health status of fish. In both species, $\mathrm{I}_{\mathrm{T}}$ of males from contaminated sites was highly significantly greater than that of S1 whatever a season $(\mathrm{p}<0.05$ or $\mathrm{p}<0.01)$. In females, $\mathrm{I}_{\mathrm{T}}$ of fish from Alibori River was significantly higher than that of $\mathrm{S} 1$ ( $\mathrm{p}<0.05$ or $\mathrm{p}<0.01$ ), except for Tilapia in S3 and Clarias in S2 during the rainy season, and Clarias in S3 during the dry season, for which $\mathrm{I}_{\mathrm{T}}$ was similar to that of $\mathrm{S} 1$ ( $\left.\mathrm{p}>0.05\right)$.

In females, $\mathrm{I}_{\mathrm{T}}$ of Clarias was significantly higher than that of Tilapia $(\mathrm{p}<0.05$ ), except in $\mathrm{S} 1$ where the difference was not significant ( $\mathrm{p}>$ 0.05 ) during the rainy season. Similarly, the trend for males at all sites was that $\mathrm{I}_{\mathrm{T}}$ of Clarias was higher than that of Tilapia. In both species, $\mathrm{I}_{\mathrm{T}}$ of males from Alibori River sites was significantly higher than $\mathrm{I}_{\mathrm{T}}$ of females $(\mathrm{p}<0.05)$.

To determine whether there was a relationship between plasma levels of E2 and the general health of males of both species, we determined the linear correlations between $\mathrm{E} 2$ and $\mathrm{I}_{\mathrm{T}}$. The results revealed high correlations between the health status of males and E2 levels. 

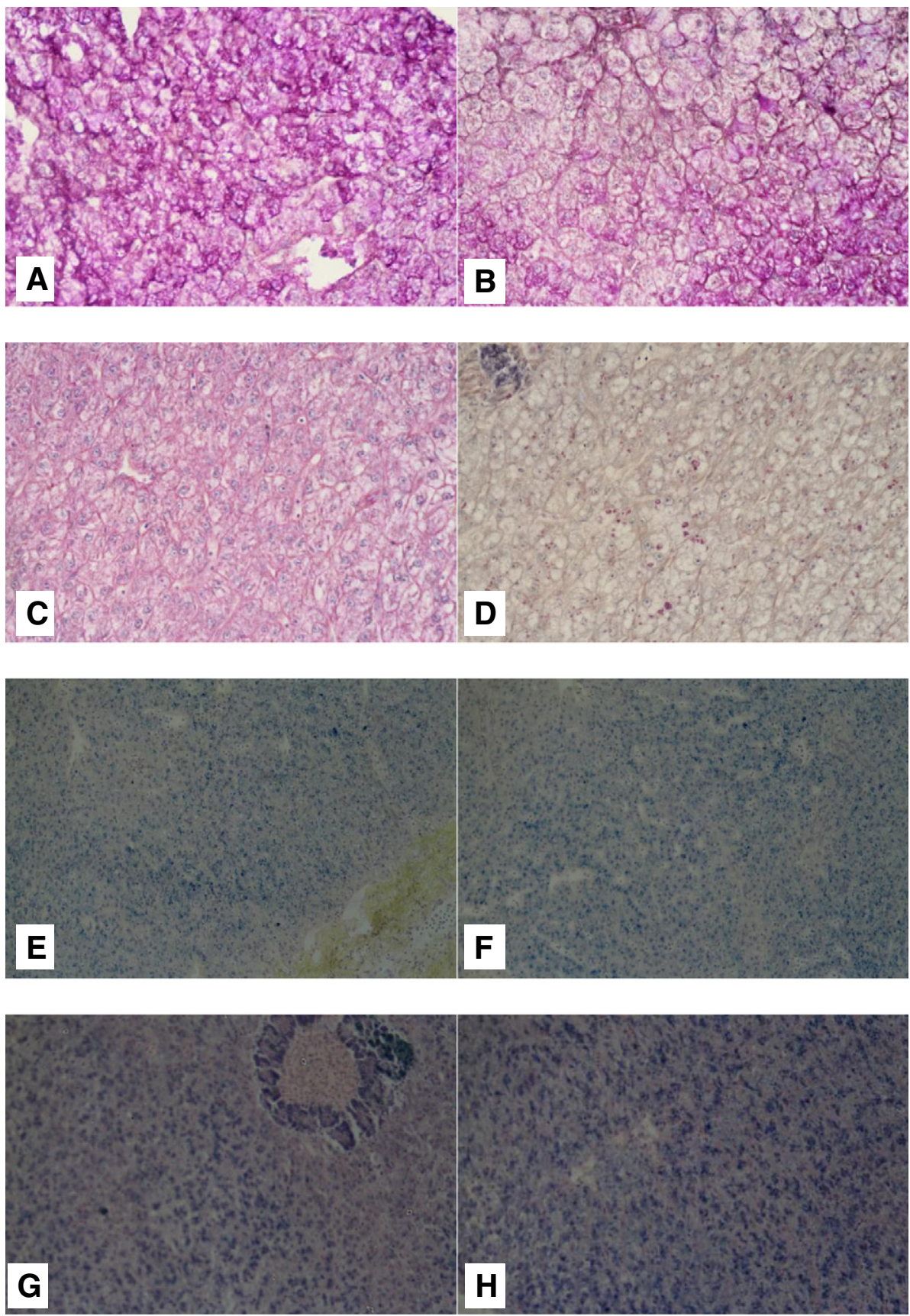

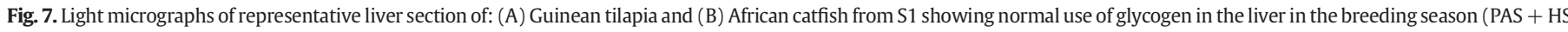

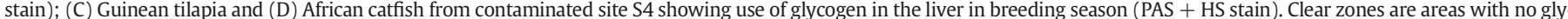

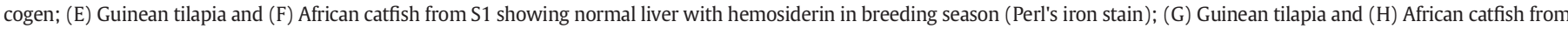

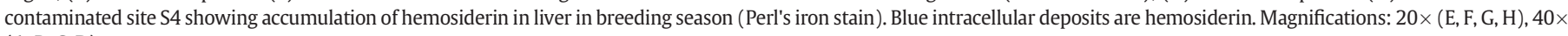
(A, B, C, D).

This correlation was highly significant for African catfish $(\mathrm{r}=0.998, \mathrm{p}=$ $0.001)$ and significant for Guinean tilapia $(r=0.898, p=0.02)$ in the rainy season (period of intense use of pesticides) while lower correlations were observed in the dry season $(r=0.832, p=0.03$ for Clarias and $\mathrm{r}=0.741, \mathrm{p}=0.04$ for tilapia).

\section{Discussion}

\subsection{Pesticide levels}

No organochlorine pesticides were found at the control site within the detection limit of $0.05 \mu \mathrm{g} / \mathrm{L}$. Endosulfan was detected in contaminated sites at lower concentrations during the dry season $(2.92-3.72 \mu \mathrm{g} / \mathrm{L})$ than during the rainy season $(8.22-13.83 \mu \mathrm{g} / \mathrm{L})$. These relatively high concentrations were recorded during a season with a heavy use of pesticides in the fields that confirmed our results based on which endosulfan is the most extensively used (75\% of total volume of pesticide) in this cotton-producing basin of Benin (Agbohessi et al., 2011). However, these values were much lower than those found by Assongba (1996) (58-746 $\mu \mathrm{g} / \mathrm{L})$ in the waters within natural area hunting zones in the W Park, which is located in the same geographical region (between north Benin, Burkina Faso and Niger). These values were higher than those obtained by Agagbé (2008) (0.293-0.471 $\mu \mathrm{g} / \mathrm{L}$ ) in the waters of the Agbado River (Savalou, 

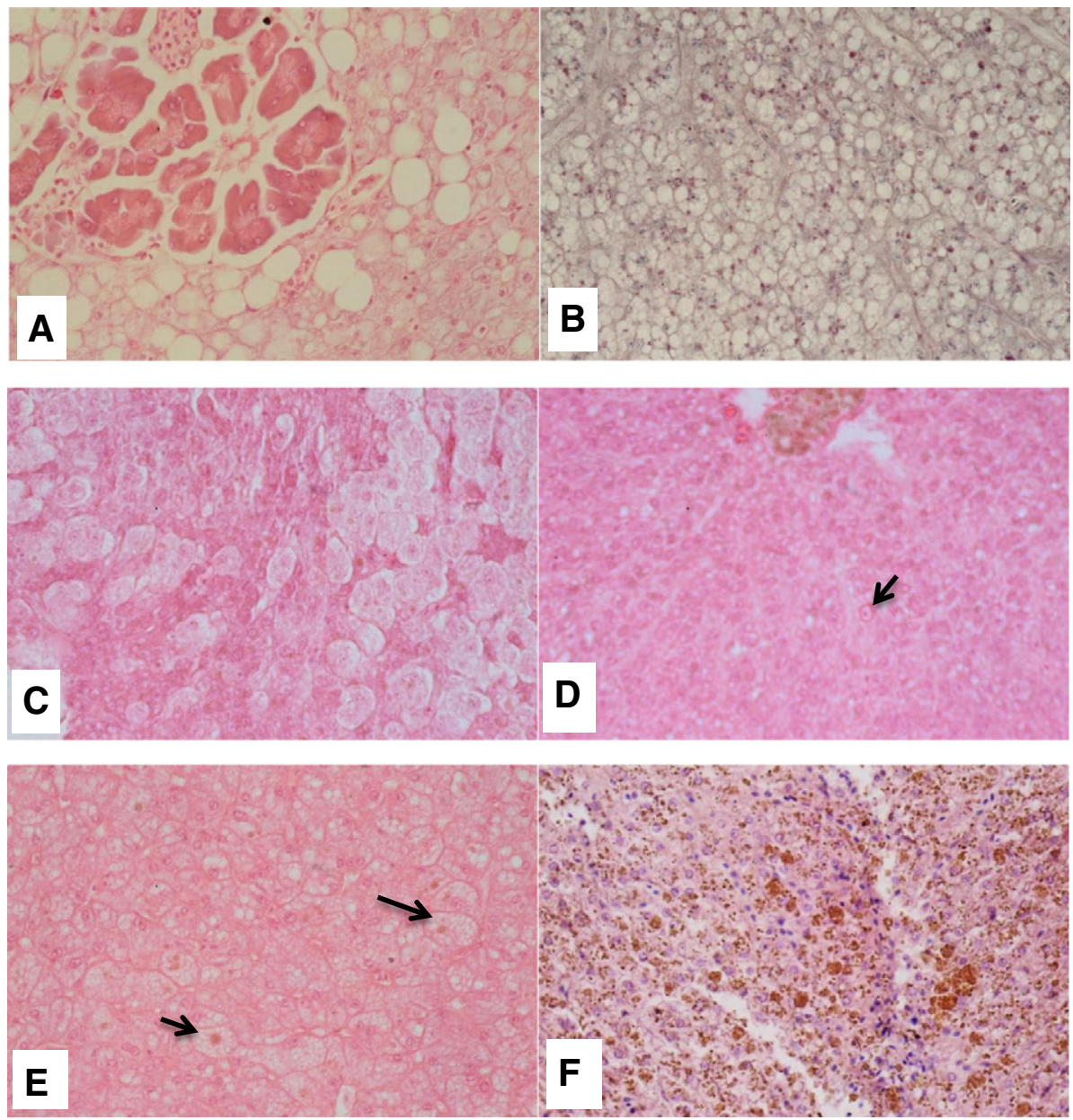

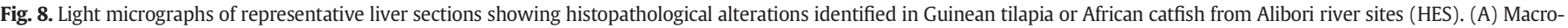

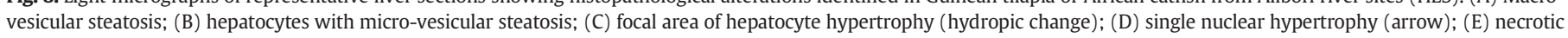
liver cells (arrows), (F) MMC. Magnification: 40×.

Benin) (0.29-0.47 $\mu \mathrm{g} / \mathrm{L})$, and higher than those found in the cottonproducing areas of Mali $(<1 \mu \mathrm{g} / \mathrm{L})$ (Dem et al., 2007) or those in the Anié River (Togo) (0.57 $\mu \mathrm{g} / \mathrm{L}$ ) (Mawussi, 2008). The highest value of $13.8 \mu \mathrm{g} / \mathrm{L}$ assayed during the rainy season was higher than the LC50 of $12.8 \mu \mathrm{g} / \mathrm{L}$ that was identified in Nile Tilapia by Tellez-Banuelos et al. (2009) and of $0.77 \mu \mathrm{g} / \mathrm{L}$, determined in African catfish by Ezemonye and Ikpesu (2011). This observation can explain the abundance of dead fish found along the riverbanks, especially at site S4 on the Alibori River during this time-period. Regardless of the season, site S4 was the most contaminated, most likely because of its position downstream from all other sites on the river, thereby receiving pollutants from them.

Contrary to endosulfan, heptachlor was detected at higher concentrations during the dry season than during the rainy one. This could be explained by the heavy use of pesticides by the local fishermen to capture the different fish (CENAGREF, 2004).

Metabolites of DDT were found at relatively low levels compared to those of endosulfan and heptachlor, and the DDE/DDT $>1$ ratios indicated that this pesticide was used in the distant past (Iwata et al., 1993).

Table 4

Total Index in Guinean tilapia and African catfish for each sampling site and season.

\begin{tabular}{|c|c|c|c|c|c|}
\hline \multirow[t]{3}{*}{ Seasons } & \multirow[t]{3}{*}{ Sites } & \multicolumn{4}{|l|}{ Total Index } \\
\hline & & \multicolumn{2}{|l|}{ Males } & \multicolumn{2}{|l|}{ Females } \\
\hline & & Guinean tilapia & African catfish & Guinean tilapia & African catfish \\
\hline \multirow[t]{4}{*}{ Flooding season } & S1 & $28.8 \pm 11.1$ & $32.0 \pm 7.7$ & $29.2 \pm 8.0$ & $35.8 \pm 7.7$ \\
\hline & S2 & $60.3 \pm 17.7^{* * a} \mathrm{a}$ & $66.3 \pm 8.5^{* * a}$ & $38.3 \pm 9.0^{*} \mathrm{Ab}$ & $49.7 \pm 14.6^{\mathrm{Bb}}$ \\
\hline & S3 & $67.2 \pm 13.5^{* * a}$ & $64.0 \pm 30.2^{* * a}$ & $36.3 \pm 4.2^{\mathrm{Ab}}$ & $52.6 \pm 10.9 * \mathrm{Bb}$ \\
\hline & S4 & $72.3 \pm 4.9^{* *} \mathrm{Aa}$ & $83.9 \pm 21.3^{* * \mathrm{Ba}}$ & $43.8 \pm 8.8^{*} \mathrm{Ab}$ & $62.4 \pm 11.2^{*} \mathrm{Bb}$ \\
\hline \multirow[t]{4}{*}{ Dry season } & S1 & $18.7 \pm 9.5^{\mathrm{A}}$ & $28.3 \pm 8.2^{\mathrm{B}}$ & $17.0 \pm 8.7^{\mathrm{A}}$ & $31.4 \pm 14.3^{\mathrm{B}}$ \\
\hline & S2 & $40.5 \pm 16.4^{*} \mathrm{Aa}$ & $62.9 \pm 15.2^{* * \mathrm{Ba}}$ & $28.3 \pm 10.3^{*} \mathrm{Ab}$ & $42.0 \pm 12.0^{*} \mathrm{Bb}$ \\
\hline & S3 & $37.8 \pm 16.3^{* A a}$ & $67.0 \pm 19.2^{* * \mathrm{Ba}}$ & $28.7 \pm 5.9^{* b}$ & $37.2 \pm 8.9^{\mathrm{b}}$ \\
\hline & S4 & $63.5 \pm 3.4^{* * a}$ & $68.4 \pm 13.2^{* * a}$ & $40.4 \pm 11.9^{* *} \mathrm{Ab}$ & $54.8 \pm 5.1^{*} \mathrm{Bb}$ \\
\hline
\end{tabular}

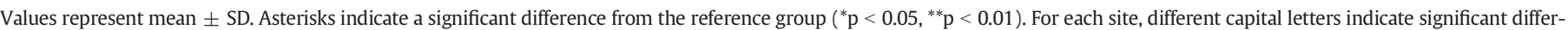
ences between species $(\mathrm{p}<0.05)$ while different small letters indicate significant differences between sexes. 
Because of its high persistence, this pesticide was still present at the different sites in the Alibori River. The low levels found in the river water are also due to its low solubility. Values of pp'-DDT (0.065-0.105 $\mu \mathrm{g} / \mathrm{L})$ assayed from the Alibori site $S 4$ were higher than those found in the biosphere reserve at the W Park (0.004-0.018 $\mu \mathrm{g} / \mathrm{L})$ (CENAGREF, 2004).

\subsection{Reproductive biomarkers}

\subsubsection{Plasma sex steroids}

Many authors have investigated the effects of agricultural pesticides on the hormonal regulation of fish reproduction (Gimeno et al., 1996; Mckinlay et al., 2008; Palma et al., 2009a, 2009b; Sayed et al., 2012; Da Cuña et al, 2013). In this study, the plasma levels of androgens ( $T$ and 11-KT) were generally lower in fish from contaminated sites (especially in fish from S4), whereas the levels of E2 were significantly higher at this site compared with fish from the reference site, regardless of the species, sex or season. Comparable variations in sex steroids have been observed in goldfish, Carassius auratus, by Spano et al. (2004) who found an increase in the plasma E2 levels together with a decrease in the $\mathrm{T}$ of males exposed to $1000 \mathrm{ppb}$ of the herbicide atrazine. A similar elevation of E2 was reported by Rajakumar et al. (2012) and Chakrabarty et al. (2012) in walking catfish, Clarias batrachus, exposed to $2.5 \mathrm{ppb}$ of endosulfan. However, in contrast to our study, these authors did not detect a decrease in the 11-KT. Singh and Singh (2008a) also found a significant decline in the 11-KT levels in Asian stinging catfish that were exposed to sub-lethal concentrations of cypermethrin over 45 days, whereas the plasma levels of E2 were not modified. In our study the simultaneous variations of E2 and T plasma levels could be explained by a stimulatory effect from pesticides on the aromatase activity, increasing the conversion of T to E2 (Simpson et al., 1994; Soverchia et al., 2005), as was suggested by the increase in the E2/T ratio in fish from the contaminated sites. Consequently, the reduction in the 11-KT could be explained by the decrease in the T levels, which would be preferably used for the biosynthesis of E2.

In both species, the levels of sex steroids tended to be higher during flooding than during the dry season. This is most likely because the period of high waters usually coincides with the breeding season of African catfish. Although Guinean tilapia breed continuously, their reproductive activity is also more intense during the rainy season (de Vlaming, 1983).

By comparing the values of the reference and contaminated sites, the changes to the plasma sex steroids were higher in African catfish than in Guinean tilapia. A possible explanation could be found in the respective position of these two fish species within the trophic chain. As a carnivorous species, African catfish are susceptible to accumulating more pesticides that effect steroidogenesis than the Guinean tilapia, which is detritivorous. Moreover, African catfish are more benthic than tilapia and are thus in close contact with sediments where large quantities of organochlorine residues have been deposited (Yèhouénou Azéhoun Pazou et al., 2006; Singh and Singh, 2008b). Both fish exhibit different behaviors and reproductive strategies.

\subsubsection{Histopathology of gonads}

A low GSI was observed in fish from the different sites from the Alibori River, particularly at S4, compared to those sampled from the Pendjari River, regardless of the season, sex and species. According to Mills et al. (2001), the decrease in the GSI is usually explained by the presence of histopathological changes in the gonads (gonad regression). In this study, the lower GSI observed in males from the contaminated sites may be related to the presence of histopathological alterations most likely resulting from exposure to agricultural pesticides as previously reported by other authors (Jobling et al., 1996; Christiansen et al., 1998; Gimeno et al., 1998; Mdegela et al., 2010; Sayed et al., 2012). In the females, the decrease in the GSI could be attributed to the degeneration of the ovaries, particularly in the downstream site of the Alibori River (S4) (Scholz and Gutzeit, 2000). Such a reduced GSI has also been observed in walking catfish that were exposed to malathion (Lal et al., 2013); in several species exposed to OCP: catfish from Guinea, Mystus tengara, common carp, Cyprinus carpio, caught in the Gomti River, and rohu, Labeo rohita, caught in the Ganga River (Singh and Singh, 2008b); and in zebrafish, Danio rerio, exposed to high doses of Butachlor (Chang et al., 2011).

The histopathological causes of testis regression identified in fish sampled from contaminated sites were primarily fibrosis, necrosis, vacuolation, immature cell release in lobular lumen, disorganization of lobular structures, and cyst disorganization and the presence of foam cells in the lobular lumen. Da Cuña et al. (2013) recently reported similar alterations in male Cichlasoma dimerus exposed to endosulfan, i.e. the release of immature cells in the lobular lumen, presence of foam cells and interstitial fibrosis, and disorganization of the lobular structure. Flammarion et al. (2000) also observed necrotic cells in the testicular tissues of chub Leuciscus (recently renamed Squalus) cephalus exposed to E2. Many histological alterations identified in males sampled in the Alibori River were also found by Louiz et al. (2009) in Black goby, Gobius niger, in Tunisia, or by Mlambo et al. (2009) in Mozambican tilapia, Oreochromis mossambicus, exposed to DDT. However, the most significant alteration in males of the species analyzed in this study was the high frequency of testicular oocytes (12.5-50\% of male samples) in fish from contaminated sites, clearly indicating the feminization process of those males. The presence of ovotestis in African catfish has been reported in males exposed to xenoestrogens (Barnhoorn et al., 2004) or in fish captured from polluted rivers in South Africa (Pieterse et al., 2010). Testicular oocytes were also found in tilapia Oreochromis spp. sampled from a polluted river in Taiwan (Sun and Tsai, 2009), in Mozambican tilapia caught in a river contaminated with DDT in South Africa (Marchand et al., 2008) as well as in spottail task, Notropis hudsonius, exposed to xenoestrogens (Aravindakshan et al., 2004). The molecular mechanisms underlying the appearance of testicular oocytes in fish are not fully understood; however, several authors have argued that the excess of estrogens are capable of inhibiting spermatogenesis in males and cause the formation of oocytes from spermatogonia (Gimeno et al., 1998; Nadzialek and Kestemont, 2010). These latter authors demonstrated that xenoestrogens (17 $\alpha$-ethinylestradiol) induced an in-vitro imbalance between apoptosis and cell proliferation in the testes of gudgeon, Gobio gobio, through their effects on some target genes such as Bcl-2 and caspase 3 (Nadzialek et al., 2010).

All ovotestis observed in this study, regardless of site, contained previtellogenic oocytes. Oocyte diameter was higher in male African catfish than in Guinean tilapia but the number of testicular oocytes per testis section was higher in male tilapia.

Spermatogenesis was rather limited in male tilapia sampled from the contaminated sites, because their testes contained only a few spermatids and spermatozoa. The testes of African catfish sampled from the Alibori River contained less spermatocytes (I and II) than the fish from the Pendjari River during the dry season and less spermatozoa during the rainy period, which corresponds to the reproductive season of this species. This regression of spermatogenesis was also observed in Summer flounder, Paralichthys dentatus, exposed to E2 and DDT, corroborating earlier findings about various fish species (Gimeno et al., 1996; Christiansen et al., 1998). The inhibition or delay of spermatogenesis is viewed as an indicator of exposure to xenoestrogens (Gimeno et al., 1996). During both seasons, the plasma E2 levels were relatively high in males from contaminated sites, whereas their 11-KT levels were rather low. 11-KT and E2 induce the mitotic division of spermatogonia but diverge in their properties (Miura et al., 2005). The mitosis induced by E2 produces only type A spermatogonia, whereas 11-KT produces late type B spermatogonia which evolve further to spermatogenesis. These changes are indicative of spermatogenesis impairment and testis functionality.

Regardless of the species and season, females displayed less histological alteration than males. The most prevalent alteration in S1 was the presence of MMC. The MMC act as focal depositories for resistant intracellular bacteria, from which chronic infections may develop (Agius 
and Roberts, 2003). At S1, these alterations were most likely due to the normal slight regression of the gonads during the low flow period (when the reproductive effort was limited), whereas alterations observed in fish from the Alibori River were most probably due to agricultural runoff during the rainy season, particularly at S4. An increase in the prevalence of MMC in Alibori River sites, however, may indicate oocyte degeneration (Roberts, 2001). Ovaries of female African catfish were more impaired and more frequently impaired than those of Guinean tilapia, most likely because of their trophic position and benthic preferences, putting them in close contact with pollutants in the sediments. There are also very different behaviors and reproductive strategies of each species. Among the high importance alterations, factor (3), the atretic pre-ovulatory follicles, was the most prevalent in both species and had the highest percentages during the rainy season at the polluted sites. Pre-ovulatory atretic follicles have been identified as key histological features indicative of endocrine disruption induced by chemicals (Van den Belt et al., 2002; Leino et al., 2005). Several authors have shown the regression of ovaries in fish treated with estrogenic pesticides. Goldfish exposed to $1000 \mu \mathrm{g} / \mathrm{L}$ of atrazine for 21 days displayed atretic oocytes (Spano et al., 2004). The presence of pre-ovulatory atretic oocytes was reported in Asian stinging catfish exposed to cypermethrin (Singh and Singh, 2008a), in African catfish sampled from an urban nature reserve in South Africa (Pieterse et al., 2010) and in Mozambique tilapia exposed to DDT (Mlambo et al., 2009).

In Guinean tilapia (during the rainy and dry seasons) and African catfish (during the rainy season only), lower proportions of late vitellogenic oocytes were observed in fish from the Alibori River compared to those from the Pendjari River. Based on the diameter of atretic follicles, we can assume that most of them were regressing from the late vitellogenic stage, whereas the size of non-regressed vitellogenic oocytes was much smaller than those from the reference site. A similar regression of the vitellogenic oocytes was reported in Atlantic cod, Gadus morhua, exposed to E2 by Meier et al. (2007).

Moreover, the variation in the different parameters depended on the different seasons at the various sites, particularly at the reference site, which indicates that the seasonality of reproduction is evident for African catfish, not only in the sex steroid levels but also in the GSI and in the stages of spermatogenesis and oogenesis found in the testes and ovaries, respectively.

\subsubsection{Histopathology of liver}

The liver plays a crucial role in detoxification and biotransformation processes. Moreover, due to their function, position and blood supply, the liver is one of the organs most affected by the presence of water pollutants (Roberts, 2001; Vander Oost et al., 2003), and it has been used as a reference for analysis of tissue damage caused by environmental toxic compounds (Amaral et al., 2002). The hepatosomatic index is the first macroscopic parameter that reflects the condition of the liver. In our study, unlike the GSI, the HSI increased in fish sampled at the different sites in the Alibori River compared to those in the Pendjari River. This increase was more notable at S4, which was located downstream in the Alibori River. Similar elevations of HSI were also observed by Van Dyk et al. (2012) in African catfish caught in rivers impacted by mining, industrial and urban effluents in South Africa, or by Corsi et al. (2003) in Grass goby, Zosterisessor ophiocephalus, caught in the Orbetello Lagoon (Italy) and exposed to chlorinated and aromatic hydrocarbons. The HSI increase can be linked, on the one hand, to macroscopic abnormalities such as stones and nodules of fat (Van Dyk et al., 2012); on the other hand, they may be attributed to the increased synthesis of vitellogenin from the stimulation of high plasma E2 levels (Mills et al., 2001). When toxic compounds exceed the detoxification level of the liver, high concentrations of a toxicant induced liver bio-transformer activity and provoked modifications in the normal hepatic structure. In this study 13 types of alterations have been identified in males and females. These lesions mainly had a regressive nature and were observed in fish from contaminated sites, especially in males of both species and females of African catfish from S4 during the rainy season. The MMC were the most prevalent alteration. The MMC have detoxification and recycling functions because they break down endogenous and exogenous materials, thereby acting as metabolic dumps. The presence of MMC is normal, but an increase in their size and frequency can be caused by environmental stressors. There are distinct clusters of pigment-containing cells found in a number of organs in fish (Agius and Roberts, 2003). These structures usually contain a variety of pigments, including melanin, lipofuscin, hemosiderin (Vigliano et al., 2006) and ceroid (Wolkea, 1992). In this study, Perl's iron staining exhibited the presence of hemosiderin in all of the MMC and in the macrophages. The predominant occurrence of hemosiderin in the MMC was reported previously in common dab, Limanda limanda (Bucke et al., 1984), Eurasian perch, Perca fluviatilis, roach, Rutilus rutilus, (Haaparanta et al., 1996), southern platyfish, Xiphophorus maculatus (Leknes, 2004) and African catfish (Van Dyk et al., 2012). The accumulation of hemosiderin in the liver leads to hepatic hemosiderosis, due to a high intake or release of iron. Liver damage may result in an elevation of aminotransferase levels (ALAT and ASAT), fibrosis and cirrhosis in humans (Lavergne-Slove and Mosnier, 2005). The presence of iron in the liver of Guinean tilapia and African catfish could be explained by the predominance of ferruginous soils in the study area. The second prevalent lesion was glycogen depletion that was observed at all sites, but more markedly in fish that were sampled from the Alibori River, especially during fish reproduction. Glycogen depletion could be due to an increase in energy expenditure in response to the increased metabolic demands caused by exposure to pesticides, as reported by different authors in fish exposed to endosulfan, organophosphates, heavy metals or to bacterial infections (Murty and Devi, 1982; Handy and Depledge, 1999; Fanta et al., 2003; Petri et al., 2006). It is usually considered as a general response to metabolic demands in the liver rather than as an indication of pollutant exposure. Another prevalent alteration, especially in females, was the presence of single necrotic cells. Cell necrosis indicates irreversible morphological changes coinciding with cell death. These changes affect both the nucleus and the cytoplasm. They are observable when the dead cell remains in a living environment and should be distinguished from autolysis (Hibiya, 1982). Most of the alterations cited above, as well as vacuolation, foci vacuolation, hypertrophy and fibrosis cells, were observed in the livers of fish sampled in the Pendjari River, but in much lower proportions. The presence of these lesions when no pesticides were applied within the watershed area and their absence in the analyzed specimens suggests that these liver alterations are occurring quite naturally within fish populations and are not necessarily induced by pollutants, but an increase in their size and frequency at the Alibori River sites can be caused by exposure to agricultural pesticides (Agius and Roberts, 2003). The degeneration observed in the case of our study is peri-lobular. Additional liver alterations detected in males and females of both species sampled in the Alibori River were hepatocellular pleomorphism, foci of clear cells, foci of necrosis, and cell hypertrophy. Similar lesions were observed in African catfish sampled from polluted rivers in South Africa by Van Dyk et al. (2012). Several investigators reported degenerative changes, lipid vacuolization, and hyaline droplets in hepatocytes of fish exposed to commercial formulations of glyphosate (Szarek et al., 2000; Jiraungkoorskul et al., 2002, 2003; Langiano and Martinez, 2008; Albinati et al., 2007 and 2009). In Nigeria, Olarinmoye et al. (2011) described hydropic degeneration, hepatic necrosis, hemosiderosis and the foci of cell alterations in the liver of brackish water catfish, Chrysitchtys nigrodigitatus that were exposed to organochlorine pesticides. In mosquitofish, Gambusia affinis, exposed to Thiodan (33.7\% of endosulfan), a significant dose and time-dependent increase of liver hypertrophy, dilatation of sinusoids and hepatocyte vacuolization was observed by Cengiz et al. (2001). Increased hepatocyte vacuolization and eosinophil granular cell aggregates were also reported after dietary exposure of endosulfan in Nile tilapia (Coimbra et al., 2007). Several other recent studies (Barja-Fernandez et al., 2013; Binkowski et al., 2013; 
Vasanthi et al., 2013) also exhibited the relationship between toxicity and lesions similar to those identified in our study in various species of fish. For these authors, the cellular and nuclear hypertrophy of hepatocytes occurred as a consequence of increased detoxification activity when fish were exposed to pollutants. Noyes et al. (2011) attributed the vacuolated nuclei to impingements caused by enlarged intrahepatic biliary passageways, a process that could also be mediating similar BDE47 effects in turbot, Psetta maxima. Nuclear vacuolization is considered to be a sign of cellular degeneration prior to necrosis (Safahieh et al., 2012). For Gingerich (1982), the vacuolization of hepatocytes might indicate an imbalance between the rate of synthesis of substances and the rate of their release into circulation. Lipid vacuolation of hepatocytes has been identified in fish as a result of fat imbalances and nutrient deficiencies (Coz-Rakovac et al., 2008). This alteration correlates with macroscopic fatty nodules identified during necropsy.

\subsection{Health indicators}

The quantitative fish health indicators used in this study (total length, weight, condition factor, It, Io and $\mathrm{I}_{\mathrm{T}}$ ) have been widely used and discussed in the literature and were selected to reflect the overall organism health of the fish. In general, the weight and the condition factor K of fish sampled from the Alibori River were lower than those from the Pendjari River. A decrease in the K of fish exposed to pollutants was also reported by Alvarez et al. (2005) in red drum (Sciaenops ocellatus), by Hanson et al. (2007) in Nile tilapia, brackish water catfish and African catfish, and by Cook et al. (2005) in zebrafish. Several hypotheses could explain the decrease in the condition factor, but the most influencing one is most likely the bioenergetic one. In fact, the presence of environmental pollutants can affect food intake and absorption by fish (Marchand et al., 2008). Even if the fish are fed properly, a significant portion of nutrients from the catabolism of food could be converted into energy to cope with the energy demand caused by the chemical stress induced by the xenobiotics (Arunachalam et al., 1980).

During the rainy season, the testis index of Guinean tilapia and African catfish from contaminated sites ranged between 26 and 35; these values are considered by Van Dyk et al. (2009a,b) as indicators of profound alterations of the testes. The It was even greater than 35 in African catfish at $\mathrm{S} 4$, indicating that the testes experienced severe damage. Van Dyk et al. (2012) also found a similar liver index in African catfish sampled from the polluted Roodeplaat River in South Africa. During the dry season, the severity of testicular lesions in African catfish from the Alibori River sites was lower, whereas the liver of corresponding fish displayed pronounced damage. In Guinean tilapia, only fish from S4 exhibited severe hepatic damage during the dry season. A comparison between the seasons clearly indicated that alterations in both organs increased during the rainy season, and this period corresponded to the intensive use of pesticides in the Alibori River basin. African catfish experienced more damage than Guinean tilapia. This can be explained, to some extent, by its trophic position and benthic feeding habits and, as a corollary, its ability to bioaccumulate lipophilic pesticides. However, no fish body concentration data are available to confirm such a hypothesis.

Although fish from contaminated sites (Guinean tilapia from S2 and S3, and African catfish from S4) displayed some severe damage in the ovaries, the alterations of female gonads were generally lower than those observed in testes and were more pronounced during the rainy season than during the dry one. Regardless of the species, sex and season, the liver was more impaired than the gonads.

Based on the histopathology of the liver and gonads, the total index $\mathrm{I}_{\mathrm{T}}$, calculated according to Bernet et al. (1999), indicated that the general health status of fish sampled in the Alibori River was much lower than for fish sampled in the Pendjari River, particularly during the rainy season, which is a period of intense reproduction for most species including African catfish and, to a lesser extent, Guinean tilapia. African catfish appears to be more affected than Guinean tilapia, and, for both species, the males are more affected than females. Strong correlations between the E2 levels in males and the $\mathrm{I}_{\mathrm{T}}$ have been established during the rainy season, indicating a huge impact from estrogenic pesticides on the general health status of these species.

In conclusion, these results indicate that agricultural pesticides significantly impair the endocrine regulation of fish living in the Beninese cotton basin, inducing severe damage to the liver and gonads and impaired health in fish populations. The effects of pesticides would most likely be one of the causes of fish stock declines and the disappearance of certain species (MEPN, 2009). However, the pesticide tissue content was not measured, and the effects reported in fish from polluted sites indicate possible contamination of their tissues. Eating fish from contaminated rivers such as the Alibori River may pose a serious risk to human health due to the negative effects associated with the bioaccumulation of pesticides in the body.

\section{Acknowledgment}

The authors are grateful to the Cell and Tissue Laboratory of the University of Namur (Belgium) and particularly to Daniel van Vlaender and Valerie De Glas for their invaluable help in the histological analysis. This study was performed with the financial support of the Commission Universitaire pour le Développement (CUD, Belgium).

\section{Appendix A. Supplementary data}

Supplementary data to this article can be found online at http://dx. doi.org/10.1016/j.scitotenv.2014.11.047.

\section{References}

Agagbé AA. Etude écotoxico-chimique des résidus de pesticides dans le bassin-versant de la rivière Agbado par la technique d'analyse ELISA en phase solide. Thèse d'ingénieur des travaux en aménagement et protection de l'environnement. Bénin: Université d'Abomey-Calavi; 2008 [65 pp.].

Agbohessi TP, Imorou Toko I, Yabi AJ, Dassoundo-Assogba JFC, Kestemont P. Caractérisation des pesticides chimiques utilisés en production cotonnière et impact sur les indicateurs économiques dans la Commune de Banikoara au nord du Bénin Int J Biol Chem Sci 2011;5:1828-41.

Agbohessi TP, Imorou Toko I, Kestemont P. Etat des lieux de la contamination des écosystèmes aquatiques par les pesticides organochlorés dans le bassin cotonnier béninois. Cah Agric 2012;21:46-56.

Agius C, Roberts RJ. Melano-macrophage centers and their role in fish pathology. J Fish Dis 2003;9:499-509.

Albinati ACL, Moreira ELT, Albinati RCB, Carvalho JV, Santos GB, Lira AD. Toxicidade aguda do herbicida Roundup_parapiaucu (Leporinus macrocephalus). Rev Bras Sau'de Prod Anim 2007;8:184-92.

Albinati ACL, Moreira ELT, Albinati RCB, Carvalho JV, De Lira AD, Santos GB, et al. Histological biomarkers - chronic toxicity for roundup in piauçu (Leporinus macrocephalus). Arq Bras Med Vet Zootec 2009;61:621-7.

Alvarez M, del C, Fuiman LA. Environmental levels of atrazine and its degradation products impair survival skills and growth of red drum larvae. Aquat Toxicol 2005;74: 229-41.

Amaral AF, Alvarado N, Maria GI, Cunha R, Hylland K, Soto M. Autometallography and metallothione in immunohistochemistry in hepatocytes of turbot (Scophthalmus maximus L.) after exposure to cadmium and depuration treatment. Biomarkers 2002; 7:491-500

Aravindakshan J, Paquet V, Gregory M, Dufresne J, Fournier M, Marcogliese DJ, et al. Consequences of xenoestrogen exposure on male reproductive function in spottail shiners (Notropis hudsonius). Toxicol Sci 2004;78:156-65.

Arunachalam S, Jeyalakshmi K, Aboubucker S. Toxic and sublethal effects of carbaryl on a fresh water Catfish, Mystus vittatus. Arch Environ Contam Toxicol 1980;9:307-16.

Association Interprofessionnelle de Coton. Plan de campagne agricole cotonnière 2009-2010 et perspective 2010-2011. Cotonou: Presse de l'AIC; 2009 [235 pp.].

Assongba M. Recherche de résidus de pesticides organochlorés et de PCBs dans les exploitations agricoles de Banikoara. Analyse par chromatographie en phase gazeuse couplée à une détection à capture d'électron (CPG/ECD). - Mémoire de fin de formation d'Ingénieur des Travaux en Techniques d'Aménagement et Protection de l'Environnement, APE/CPU; 1996 [196 pp.].

Australian Pesticides and Veterinary Medicines Authority. Evaluation of the new active flubendiamide in the production BELT 480 SC insecticide and BELT 240 WG insecticide. Commonwealth of Australia Gazette No. APVMA 2-3 Février 2009. Agricultural and veterinary chemicals code Act 1994; 2009 [http://www.apvma.gov.au/ registration/ assessment/ docs/prs flubendiamide.pdf. Accessed 28 Dec 2013].

Barja-Fernandez S, Miguez JM, Alvarez-Otero R. Histopathological effects of 2,2',4,4'tetrabromodiphenyl ether (BDE-47) in the gills, intestine and liver of turbot (Psettc maxima). Ecotoxicol Environ Saf 2013;95:60-8. 
Barnhoorn IEJ, Bornman MS, Pieterse GM, Van Vuren JHJ. Histological evidence of intersex in feral sharptooth catfish (Clarias gariepinus) from an estrogen-polluted water source in Gauteng, South Africa. Environ Toxicol 2004;19:603-8.

Barse AV, Chakrabarti T, Ghosh TK, Pal AK, Jadhao SB. Endocrine disruption and metabolic changes following exposure of Cyprinus carpio to diethyl phthalate. Pest Biochem Physiol 2007;88:36-42.

Bernet D, Schmidt H, Meier W, Berkhardt-Holm P, Wahli T. Histopathology in fish: proposal for a protocol to assess aquatic pollution. J Fish Dis 1999;22:25-43.

Binkowski QJ, Sawicka-Kapusta K, Szarek J, Strzyzewska E, Felsmann M. Histopathology of liver and kidneys of wild living Mallards Anas platyrhynchos and Coots Fulica atra with considerable concentrations of lead and cadmium. Sci Total Environ 2013;450/ 451:326-33.

Boumaiza M, Ktari MH, Vitiello P. Acute toxicity for Aphanius fasciatus of various pesticides used in Tunisia. Arch Inst Pasteur Tunis 1979;56:307-42.

Bucke D, Watermann B, Feist S. Histological variations of hepato-splenic organs from the North Sea dab, Limanda limanda (L.). J Fish Dis 1984;7:255-68.

Cek S, Yilmaz E. Gonad development and sex ratio of sharptooth catfish (Clarias gariepinus Burchell, 1822) cultured under laboratory conditions. Turk J Zool 2007;31:35-46.

CENAGREF (Centre National de Gestion des Réserves de Faune). Etude de l'impact de l'utilisation des engrais chimiques et des pesticides par les populations riveraines sur les écosystèmes (eau de surface, végétaux et faunes) des Aires Protégées (Parcs Nationaux et zones cynégétiques) du Bénin. Rapport final d'expertise; 2004. [168 pp.].

Cengiz EI, Unlu E, Balci K. The histopathological effects of thiodan on the liver and gut of mosquitofish, Gambusia affinis. J Environ Sci Health B 2001;36:75-85.

CeRPA-Borgou/Alibori. (Centre Régional pour la promotion Agricole Borgou-Alibori) Rapport du constat de l'empoisonnement d'une poche d'eau du fleuve Ouémé supérieur: 2013 [27 pp.].

Chakrabarty S, Rajakumar A, Raqhuveer K, Sridevi P, Mohanachary A, Prathibha Y, et al. Endosulfan and flutamide, alone and in combination, target ovarian growth in juvenile catfish, Clarias batrachus. Comp Biochem Physiol Part C 2012;155:491-7.

Chang J, Liu S, Zhou S, Wang M, Zhu G. Effects of butachlor on reproduction and hormone levels in adult zebrafish (Danio rerio). Exp Toxicol Pathol 2011;65:205-9.

Chao W, Guanghua L, Jing C, Perfang W. Sub-lethal effects of pesticide mixtures on selected biomarkers of Carassius auratus. Environ Toxicol Pharmacol 2009;28:414-9.

Chen H, Xiao J, Hu G, Zhou J, Xiao H, Wang X. Estrogenicity of organophosphorus and pyrethroid pesticides. J Toxicol Environ Health A 2002;65:1419-35.

Chinah AC, Sikoki FD, Vincent-Akpu I. Toxicity of an organophosphate pesticide (chlorpyrifos) on a common Niger Delta wetland fish Tilapia Guineensis (Blecker 1862). J Appl Sci Environ Manag 2004;8:11-7.

Christiansen T, Korsgaard B, Jespersen A. Effects of nonylphenol and 17- $\beta$ oestradiol on vitellogenin synthesis, testicular structure and cytology in male eelpout (Zoarces viviparous). J Exp Biol 1998;201:179-92.

Coimbra AM, Figueiredo-Fernandes A, Reis-Henriques MA. Nile tilapia (Oreochromis niloticus), liver morphology, CYP1A activity and thyroid hormones after endosulfan dietary exposure. Pest Biochem Physiol 2007;89:230-6.

Cook LW, Paradise CJ, lom B. The pesticide malathion reduces survival and growth in developing zebrafish. Environ Toxicol Chem 2005;24:1745-50.

Corsi I, Mariottini M, Sensini C, Lancini L, Focardi S. Cytochrome P450, acetylcholinesterase and gonadal histology for evaluating contaminant exposure levels in fishes from highly eutrophic brackish ecosystem: the Orbetello Lagon, Italy. Mar Pollut Bull 2003; 46:203-12.

Coz-Rakovac R, Strunjak-Perovic I, Topicpopovic N, Hacmanjek M, Smuc T, Jadan M, et al. Cage culture effects on mullets (Mugilidae) liver histology and blood chemistry profile. J Fish Biol 2008;72:2557-69.

Da Cuña RH, Pandolfi M, Genovese G, Piazza Y, Ansaldo M, Lo Nostro FL. Endocrine disruptive potential of endosulfan on the reproductive axis of Cichlasoma dimerus (Perciformes, Cichlidae). Aquat Toxicol 2013;126:299-305.

De Vlaming VL. Oocyte development patterns and hormone involvements among teleosts. In: Rankin JC, Pitcher TJ, Duggan TJ, editors. Control processes in Fish physiol. London: Croom Helm; 1983. p. 176-99.

Dem SB, Cobb JM, Mullins DE. Pesticide residues in soil and water from four cotton growing areas of Mali, West Africa. J Agric Food Environ Sci 2007;1:1-12.

Ezemonye LIN, Ikpesu TO. Evaluation of sub-lethal effects of endosulfan on cortisol secretion, glutathione S-transferase and acetylcholinesterase activities in Clarias gariepinus. Food Chem Toxicol 2011;49:1898-903.

Fanta E, Rios FS, Romano S, Vianna ACC, Freiberger S. Histopathology of the fish Corydoras paleatus contaminated with sub-lethal levels of organophosphorus in water and food. Ecotoxicol Environ Saf 2003;54:119-30.

Flammarion P, Devaux A, Garric J. Marqueurs biochimiques de pollution dans les écosystèmes aquatiques continentaux. Exemples d'utilisation et perspectives pour les gestionnaires. Bull Fr Pêche Piscic 2000;257/258:209-26.

Foerson LL, DeFur PL, Tuberty S. Effects of endosulfan on moulting in juvenile red swamp crayfish, Procambarus clarkii. Annual meeting of the Society of Environmental Toxicology and Chemistry. Baltimore MD, Pensacola FL: SETAC Press; 2001

Fostier A, Jalabert B. Steroidogenesis in rainbow trout (Salmo gairdneri) at various preovulatory stages: changes in plasma hormone levels and in vivo and in vitro responses of the ovary to salmon gonadotropin. Fish Physiol Biochem 1986;2:87-99.

Gillium RJ. Pesticides in U.S. streams and groundwater. Environ Sci Technol 2007;41: 3407-13.

Gimeno S, Gerritsen A, Bowmer T, Komen H. Feminization of male carp. Nature 1996;384 $221-2$.

Gimeno S, Komen H, Jobling S, Sumpter J, Bowmer T. Demasculinisation of sexually mature male common carp, Cyprinus carpio, exposed to 4-tert-pentylphenol during spermatogenesis. Aquat Toxicol 1998;43:93-109.
Gingerich WH. Hepatic toxicology of fishes. In: Weber LJ, editor. Aquat toxicolNew York, NY: Raven Press; 1982. p. 55-105.

Gounou A. Etude d'impact environnemental et social de l'installation d'une réserve villageoise dans la Commune de Banikoara. Rapport définitif de la mission 003/08/ ED/CGP, publie' par l'Association ED, CENAGREF Fondation IGF, Cotonou, Benin, West Africa; 2009.

Grébil G, Novak S, Perrin-Ganier C, Schavion M. La dissipation des produits phytosanitaires appliqués au sol. Ingénieries $\mathrm{N}^{\circ}$ special; 2001. p. 31-44.

Gul A. Investigation of acute toxicity of chlorpyrifos - methyl on Nile tilapia (Oreochromis niloticus L.) larvae. Chemosphere 2005;59:163-6.

Haaparanta A, Valtonen ET, Hoffmann R, Holmes J. Do macrophage centers in freshwater fishes reflect the differences in water quality? Aquat Toxicol 1996;34:253-72.

Handy RD, Depledge MH. Physiological responses: their measurement and use as environmental biomarkers in ecotoxicology. Ecotoxicol 1999;8:329-49.

Hanson R, Dadoo DK, Essumang DK, Blay J, Kjr Yankson. The effect of some selected pesticides on the growth and reproduction of fresh Oreochromis niloticus, Chrysicthys nigrodigitatus and Clarias gariepinus. Bull Environ Contam Toxicol 2007;79:544-7.

Hayes TB, Case P, Chui S, Chung D, Haeffele C, Haston K, et al. Pesticide mixtures, endocrine disruption, and amphibian declines: are we underestimating the impact? Environ Health Persp 2006;114:40-50.

Hibiya T. An atlas of fish histology: normal and pathological features, Kodansha Ltd. Tokyo; 1982.

Idieti ME. Variabilité hydro-climatique dans le basin versant de la Pendjari au Bénin (Nord-Ouest du Bénin). Université d'Abomey-Calavi; 2009 [59 pp.].

Iwata H, Tanabe S, Sakal N, Tatsukawa R. Distribution of persistent organochlorines in the oceanic air and surface seawater and the role of ocean on their global transport and fate. Environ Sci Technol 1993;27:1080-98.

Jiraungkoorskul W, Upatham ES, Kruatrachue M, Sahaphong S, Vichasri-Grams S, Pokethitiyook P. Histopathological effects of round up, a glyphosate herbicide on Nile tilapia (Oreochromis niloticus). Sci Asia 2002;28:121-7.

Jiraungkoorskul W, Upatham ES, Kruatrachue M, Sahaphong S, Vichasri-Grams S, Pokethitiyook P. Biochemical and histopathological effects of glyphosate herbicide on Nile tilapia (Oreochromis niloticus). Environ Toxicol 2003;18:260-7.

Jobling S, Sheahan D, Osborne JA, Matthiessen P, Sumpter JP. Inhibition of testicular growth in rainbow trout (Oncorhynchus mykiss) exposed to estrogenic alkylphenolic chemicals. Environ Toxicol Chem 1996;15:194-202.

Katary A. Etude spatio-temporelle de la gestion de la résistance de Helicoverpa armigera (Hubner, 1808) aux Pyréthrino des en culture cotonnière au Bénin. Thèse de Docteur d'Etat ès Sciences Naturelles de l'Université d'Abomey-Calavi (Bénin); 2004 [331pp.].

Lal B, Sarang MK, Kumar P. Malathion exposure induces the endocrine disruption and growth retardation in the catfish Clarias batrachus (Linn). General and Comparative Endocrinology 2013;181:139-45.

Langiano VC, Martinez CBR. Toxicity and effects of a glyphosate based herbicide on the neotropical fish Prochilodus lineatus. Comp Biochem Physiol Part C 2008;147:222-31.

Lavergne-Slove A, Mosnier JF. Lésions élémentaires des cellules, tissus et organes (Chapitre 2). Copyright AFECAP; 2005 [27 pp.].

Leino RL, Jensen KM, Ankley GT. Gonadal histology and characteristic histopathology associated with endocrine disruption in the adult fathead minnow (Pimephales promelas). Environ Toxicol Pharmacol 2005;19:85-98.

Leknes IL. Melano-macrophage centers in liver of platyfish, Xiphophorus maculatus, Poeciliidae: Teleostei. Zool 2004;107:201-4.

Le Mer C, Roy LR, Pellerin J, Couillard CM, Maltais D. Effects of chronic exposures to the herbicides atrazine and glyphosate to larvae of the threespine stickleback (Gasterosteus aculeatus). Ecotoxicol Environ Saf 2013;89:174-81.

Louiz I, Ben-Attia M, Ben-Hassine OK. Gonadosomatic index and gonad histopathology of Gobius niger (Gobiidea, Teleost) from Bizerta lagoon (Tunisia): evidence of reproduction disturbance. Fish Sci 2009;100:266-73.

Mandiki SN, Houbart M, Babiak I, Vandeloise E, Gardeur JN, Kestemont P. Are sex steroids involved in the sexual growth dimorphism in Eurasian perch juveniles? Physiol Behav 2004;80:603-9.

Marchand MJ, Pieterse GM, Barnhoorn IEJ. Sperm motility and testicular histology of two feral fish species from a currently DDT-sprayed area, South Africa. J Appl Ichthyol 2008;24:423-9.

Mawussi G. Bilan environnemental de l'utilisation de pesticides organochlorés dans les cultures de coton, café et cacao au Togo et recherches d'alternatives par l'évaluation du pouvoir insecticide d'extraits de plantes locales contre le scolyte du café (Hypothenemus hampei ferrari). Thèse de doctorat de l'université de Toulouse; 2008 [http://ethesis.inp-toulouse.fr/archive/00000935/01/mawussi.pdf].

McCarthy AR, Thomson BM, Shaw IC, Abella AD. Estrogenicity of pyrethroid insecticide metabolites. J Environ Monit 2006;8:197-202.

McKinlay R, Plant JA, Bell JNB, Voulvoulis N. Endocrine disrupting pesticides: implications for risk assessment. Environ Int 2007;34:170-2.

Mckinlay R, Plant JA, Bell JNB, Voulvoulis N. Endocrine disrupting pesticides: implications for risk assessment. Environ Int 2008;34:168-83.

Mdegela RH, Braathen M, Mosha RD, Skaare JU, Sandvik M. Assessment of pollution in sewage ponds using biomarker responses in wild African sharptooth catfish (Clarias gariepinus) in Tanzania. Ecotoxicol 2010;19:722-34.

Meier S, Andersen TE, Norberg B, Thorsen A, Taranger GL, Kjesbu OS, et al. Effects of alkylphenols on the reproductive system of Atlantic Cod (Gadus morhua). Aquat Toxicol 2007;81:207-18.

MEPN (Ministère de l'Environnement et de la Protection de la Nature). Quatrième rapport national du Bénin sur la convention des Nations Unies sur la diversité biologique; 2009.

Micheletti C, Critto A, Marcomini A. Assessment of ecological risk from bioaccumulation of PCDD/Fs and dioxin-like PCBs in a coastal lagoon. Environ Int 2007;33:45-55. 
Mills LJ, Gutjahr-Grobell RE, Haebler RA, Borsay Horowitz DJ, Jayaraman S, Pruell RJ, et al. Effects of estrogenic (o,p_-DDT; octylphenol) and anti-androgenic (p,p_-DDE) chemicals on the indicators of endocrine status in juvenile male summer flounder (Paralichthys dentatus). Aquat Toxicol 2001;52:157-76.

Miura C, Takahashi N, Michino F, Miura T. The effect of paranonylphenol on Japanese eel (Anguilla japonica) spermatogenesis in vitro. Aquat Toxicol 2005;71:133-41.

Mlambo SS, van Vuren JHJ, Barnhoorn IEJ, Bornman MS. Histopathological changes in the reproductive system (ovaries and testes) of Oreochromis mossambicus following exposure to DDT. Environ Toxicol Pharmacol 2009;28:133-9.

Murty AS, Devi AP. The effect of endosulfan and its isomers on tissue protein, glycogen, and lipids in the fish Channa punctata. Pest Biochem Physiol 1982;17:280-6.

Nadzialek S, Kestemont P. $17 \alpha$-Ethinylestradiol induces an imbalance between apoptosis and cell proliferation in a testis culture of gudgeon Gobio gobio. Environ Toxicol Chem 2010;29:881-6.

Nadzialek S, Pigneur LM, Wéron B, Kestemont P. Bcl-2 and caspase 3 mRNA levels in the testes of gudgeon, Gobio gobio, exposed to ethinylestradiol (EE2). Aquat Toxicol 2010;98:304-10.

Noyes PD, Hinton DE, Stapleton HM. Accumulation and debromination of decabromodiphenyl ether (BDE-209) in juvenile fathead minnows (Pimephales promelas) induces thyroid disruption and liver alterations. Toxicol Sci 2011;122: 265-74.

Okounmassoun L, Brochu C, Deblois C. Vitellogenin in tilapia male fishes exposed to organochlorine pesticides in Ouémé River in Republic of Benin. Sci Total Environ 2002;299:163-72.

Olarinmoye OM, Taiwo VO, Clarke EO, Kumolu-Johson CA, Aderinola OJ, Adekunbi F. Hepatic pathologies in the brakish water catfish (Chrysicthys nigrodigitatus) from contaminated locations of the Lagos lagoon complex. Afr J Biotechnol 2011;10:15058-64.

OMS. Environmental health criteria 124 Lindane; 1991 [28 pp.].

OMS-PNUE. Etat de l'art sur les perturbateurs endocriniens. Extraits choisis concernant les pesticides perturbateurs endocriniens. Publication state of the science of endocrine disrupting chemicals 2012. Rapport OMS-PNUE; 2013 [15 pp.].

Oruç EÖ. Oxidative stress, steroid hormone concentrations and acetylcholinesterase activity in Oreochromis niloticus exposed to chlorpyrifos. Pest Biochem Physiol 2010;96: 160-6.

Palma P, Palma VL, Fernandes RM, Soares AMVM, Barbosa IR. Acute toxicity of atrazine, endosulfan sulphate and chlorpyrifos to Vibrio fischeri, Thamnocephalus platyurus and Daphnia magna, relative to their concentrations in surface waters from the Alentejo region of Portugal. Bull Environ Contam Toxicol 2008;81:485-9.

Palma P, Palma VL, Fernandes RM, Soares AMVM, Barbosa IR. Endosulfan sulphate interferes with reproduction, embryonic development and sex differentiation in Daphnia magma. Ecotoxicol Environ Saf 2009a;72:344-50.

Palma P, Palma VL, Matos C, Fernandes RM, Bohn A, Soares AMVM, et al. Assessment of the pesticides atrazine endosulfan sulphate and chlorpyrifos for juvenoid-related endocrine activity using Daphnia magna. Chemosphere 2009b;76:335-40.

Pazou EY, Lalèyè P, Boko M, van Gestel CA, Ahissou H, Akpona S, et al. Contamination of fish by organochlorine pesticide residues in the Ouémé River catchment in the Republic of Benin. Environ Int 2006;32:594-9.

Petri D, Glover CN, Ylving S, Kolås K, Fremmersvik G, Waagbø R, et al. Sensitivity of Atlantic salmon (Salmo salar) to dietary endosulfan as assessed by haematology, blood biochemistry, and growth parameters. Aquat Toxicol 2006;80:207-16.

Pieterse GM, Marchand MJ, van Dyk JC, Barnhoorn IEJ. Histological alterations in the testes and ovaries of the sharptooth catfish (Clarias gariepinus) from an urban nature reserve in South Africa. J Appl Ichthyol 2010;26:789-93.

Primentel D, Levitain LC. Pesticides. Amounts applied and amount reaching pests. Often, less than $0.1 \%$ of pesticides applied to crop reach target pests. Biosci 1986;36:86-91.

Purdom CE, Hardiman PA, Bye VJ, Eno NC, Tyler CR, Sumpter JP. Estrogenic effects of effluents from sewage treatment works. Chem Ecol 1994;8:275-85.

Rajakumar A, Singh R, Chakrabarty S, Murugananthkumar R, Laldinsangi C, Prathibha Y, et al. Endosulfan and flutamide impair testicular development in the juvenile Asian catfish, Clarias batrachus. Aquat Toxicol 2012;110/111:123-32.

Rajapakse N, Silva E, Kortenkamp A. Combining xenoestrogens at levels below individual no-observed effect concentration dramatically enhances steroid hormone action. Environ Health Perspect 2002;10:917-21.

Rinchard J, Kestemont P. Comparative study of reproductive biology in single and multiple spawned cyprinid fish. Morphological and histological features. J Fish Biol 1996; 49:883-94.

Roberts RJ. Fish pathology. 3rd Ed WB Saunders; 2001. [Philadelphia].

Rotchell JM, Ostrander GK. Molecular markers of endocrine disruption in aquatic organisms. J Toxicol Environ 2003;302:167-84.

Safahieh A, Hedayati A, Savari A, Movahedinia A. Effect of sub-lethal dose of mercury toxicity on liver cells and tissue of yellow sea bream. Toxicol Ind Health 2012;28:583-92.

Sayed Ael-D, Mahmoud UM, Mekkawy IA. Reproductive biomarkers to identify endocrine disruption in Clarias gariepinus exposed to 4-nonylphenol. Ecotoxicol Environ Saf 2012;78:310-9.

Scholz S, Gutzeit HO. 17-Alpha-ethinylestradiol affects reproduction, sexual reproduction, sexual differentiation and aromatase gene expression of the medaka (Oryzias latipes). Aquat Toxicol 2000;50:363-73.
Simpson ER, Mahendroo MS, Means GD, Kilgore MW, Hinshelwood MM, GrahamLaurence S, et al. Aromatase cytochrome P450, the enzyme responsible for estrogen biosynthesis. Endocrinol Rev 1994;15:342-54.

Singh PB, Singh V. Exposure and recovery response of isomers of $\mathrm{HCH}$, metabolites of DDT and estradiol-17ß in the female catfish, Heteropneustes fossilis. Environ Toxicol Pharmacol 2007;24:245-51.

Singh PB, Singh V. Bioaccumulation of hexachlorocyclohexane, dichlorodiphenyltrichloroethane, and estradiol-17ß in catfish and carp during pre-monsoon season in India. Fish Physiol Biochem 2008a;34:25-36.

Singh PB, Singh V. Pesticide bioaccumulation and plasma sex steroids in fishes during breeding phase from north India. Environ Toxicol Pharmacol 2008b;25:342-50.

Soso AB, Barcellos LJG, Ranzani-Paiva MJ, Kreutz LC, Quevedo RM, Anziliero D, et al. Chronic exposure to sub-lethal concentration of a glyphosate-based herbicide alters hormone profiles and affects reproduction of female Jundia (Rhamdia quelen). Environ Toxicol Pharmacol 2007;23:308-13.

Soverchia L, Ruggeri B, Palermo F, Mosconi G, Cardinaletti G, Scortichini G, et al. Modulation of vitellogenin synthesis through estrogen receptor beta- 1 in goldfish (Carassius auratus) juveniles exposed to $17-\beta$ estradiol and Nonylphenol. Toxicol Appl Pharmacol 2005;209:236-43.

Spano L, Tyler CR, van Aerle R, Devos P, Mandiki SN, Silvestre F, et al. Effects of atrazine on sex steroid dynamics, plasma vitellogenin concentration and gonad development in adult goldfish (Carassius auratus). Aquat Toxicol 2004;66:369-79.

Srivastava AK, Srivastava AK. Effect of chlordecone on gonads of freshwater catfish Heteropneustes fossilis. Bull Environ Contam Toxicol 1991;53:186-91.

Sun PL, Tsai SS. Intersex tilapia (Oreochromis spp) from a contaminated river in Taiwan: a case study. Toxins 2009;1:14-24.

Szarek J, Siwicki A, Andrzejewska A, Terech-Majewska E, Banaszkiewickz T. Effects of the herbicide roundup on the ultrastructural pattern of hepatocytes in carp (Cyprinus carpio). Mar Environ Res 2000;50:263-6.

Tellez-Banuelos MC, Casa-Solis J, Bravo-Cuellar A, Zaitseva G. Oxidative stress in macrophages from spleen of Nile tilapia (Oreochromis niloticus) exposed to sub-lethal concentration of endosulfan. Fish Shellfish Immunol 2009;27:105-11.

Tripathi G, Shasmal J. Concentration related responses of chlorpyriphos in antioxidant anaerobic and protein synthesizing machinery of the freshwater fish Heteropneustes fossilis. Pest Biochem Physiol 2011;99:215-20.

Van den Belt K, Wester P, van der Ven LTM, Verheyen R, Witters H. Time-dependent effects of ethynylestradiol on the reproductive physiology in zebrafish (Danio rerio). Environ Toxicol Chem 2002;21:767-75.

Van Dyk JC, Pieterse GM. A histo-morphological study of the testis of the sharptooth catfish (Clarias gariepinus) as reference for future toxicological assessments. J Appl Ichthyol 2008;24:415-22.

Van Dyk JC, Marchand MJ, Smit NJ, Pieterse GM. A histology-based fish health assessment of four commercially and ecologically important species from the Okavango Delta panhandle, Botswana. Afr J Aquat Sci 2009a;34:273-82.

Van Dyk JC, Marchand MJ, Pieterse GM, Barnhoon IEJ, Bornman MS. Histological changes in gills of Clarias gariepinus (Teleosti: Clariidae) from a polluted South African urban aquatic system. Afr J Aquat Sci 2009b;34:283-91.

Van Dyk JC, Cochrane MJ, Wagenaar GM. Liver histopathology of the sharptooth catfish Clarias gariepinus as a biomarker of aquatic pollution. Chemosphere 2012;87:301-11.

Vander Oost R, Beyer J, Vermeulen NPE. Fish bioaccumulation and biomarkers in environmental risk assessment: a review. Environ Toxicol Pharmacol 2003;13:57-149.

Vasanthi A, Revathi P, Mini J, Munuswamy N. Integrated use of histological and ultrastructural biomarkers in Mugil cephalus for heavy metal pollution in Ennore estuary, Chennai. Chemosphere 2013;91:1156-64.

Vigliano FA, Bermúdez R, Quiroga MI, Nieto JM. Evidence for melano-macrophage centers of teleost as evolutionary precursors of germinal centers of higher vertebrates: an immuno-histochemical study. Fish Shellfish Immunol 2006;21:467-71.

Villaverde J, Hildebrandt A, Martinez E, Lacorte S, Morillo E, Maqueda C, et al. Priority pesticides and their degradation products in river sediments from Portugal. Sci Total Environ 2008;390:507-13.

Wester PW. Histopathological effects of environmental pollutants $\mathrm{HCH}$ and methyl mercury on reproductive organs in freshwater fish. Comp Biochem Physiol 1991;100: 237-9.

Wolkea RE. Piscine macrophage aggregates: a review. Annu Rev Fish Dis 1992;2:91-108

WWF (World Wildlife Fund for nature). Perturbateurs endocriniens et biodiversité. Rapport France; 2011 [24 pp.]

Yèhouénou Azéhoun Pazou E. Les résidus de pesticides chimiques de synthèse dans les eaux, les sédiments et les espèces aquatiques du bassin versant du fleuve Ouémé et du lac Nokoué. Thèse de doctorat unique de l'université d'Abomey-Calavi (Bénin); 2005 [167 pp.].

Yèhouénou Azéhoun Pazou E, Lalèyè P, Boko M. Contamination of fish by organochlorine pesticide residues in the Ouémé River catchment in the Republic of Bénin. Environ Int 2006;32:594-9.

Zimmerli S, Bernet D, Burkhardt-Holm P, Schmidt-Posthaus H, Vonlanthen TW, Segner H. Assessment of fish health status in four Swiss rivers showing a decline of brown trout catches. Aquat Sci 2007;69:11-25. 